Open Access

\title{
Foreign institutional investors and stock return comovement
}

\author{
Li Jiang ${ }^{1 *}$, Jeong-Bon Kim² and Lei Pang ${ }^{3}$
}

\author{
* Correspondence: \\ afljiang@polyu.edu.hk \\ ${ }^{1}$ School of Accounting and Finance, \\ Hong Kong Polytechnic University, \\ Hong Kong, China \\ Full list of author information is \\ available at the end of the article
}

\begin{abstract}
We investigate whether foreign institutional investors facilitate firm-specific information flow in the global market. Specifically, using annual institutional ownership data from firms across 40 countries, we find that foreign institutional ownership is negatively associated with excess stock return comovement. Our results are more pronounced when foreign institutional investors originate from common-law countries and hold a large equity stake in invested firms; and when the invested firms are located in civil-law countries. Overall, the evidence suggests that foreign institutional investors from countries with strong investor protection play an important informational role in mitigating excess stock return comovement around the world.

Keywords: Foreign institutional investors, Stock return comovement, Firm-specific information, Investor protection

JEL Classification: G14, G15
\end{abstract}

\section{Background}

There has been dramatic growth in foreign institutional investment in global capital markets over the past few decades (Karolyi, 2006). Researchers have so far focused on the monitoring role played by foreign institutional investors in firms in which they invest. For example, foreign institutional investors are credited with promoting domestic firms' corporate governance (Gillan and Starks, 2003). Foreign institutional investors play a more active monitoring role than domestic institutional investors, because foreign institutional investors are less likely to seek business relationships with local firms (Ferreira and Matos, 2008). Aggarwal et al. (2011) find a positive relation between foreign institutional ownership and firm-level governance efficacy. However, an unexplored but equally important question is whether foreign institutional investors play an informational role in influencing firms' information environment. To fill this gap, we investigate whether foreign institutional investors facilitate firm-specific information flows in the global market, thereby mitigating excess stock return comovements.

A growing body of research has established firm-specific return variation as an effective measure of firm private information impounded into stock price. French and Roll (1986) and Roll (1988) show that neither market returns nor public news explain stock return variation, suggesting that firm-specific return variation captures the

(c) The Author(s). 2018 Open Access This article is distributed under the terms of the Creative Commons Attribution 4.0 International License (http://creativecommons.org/licenses/by/4.0/), which permits unrestricted use, distribution, and reproduction in any medium, provided you give appropriate credit to the original author(s) and the source, provide a link to the Creative Commons license, and indicate if changes were made. 
impounding of private information into stock price. An influential study by Morck et al. (2000) finds that stock returns are less synchronous in developed markets with relatively strong property rights protection (and thus fewer impediments to informed trading) than in emerging markets with relatively poor protection, supporting the notion that firm-specific return variation is associated with the intensity of information-based trading. Empirical studies have largely supported their conclusions (Brockman and Yan, 2009; Durnev et al., 2003; Gul et al., 2009; Hutton et al., 2009; Kim and Shi, 2012). Piotroski and Roulstone (2004) show that insider trading reduces stock return synchronicity. Fernandes and Ferreira (2009) show that the enforcement of insider trading laws encourages informed risk arbitrage, which in turn facilitates the impounding of firm-specific information into stock prices. Ye (2012) shows that active institutional investors mitigate excessive stock return comovement caused by noise traders.

The key argument of Morck et al. (2000) rests on the intensity of risk arbitrage by informed investors in incorporating firm-specific information into stock price. ${ }^{1}$ Acquiring firm-specific versus common information has different fixed costs and generates different arbitrage profits. Investors therefore have different incentives to acquire firm-specific versus common information. Veldkamp's (2006) model shows that investors' information choice depends on their ability to bear the fixed cost of acquiring firm-specific versus common information. To ensure a low cost, investors and analysts tend to rely on information useful for evaluating multiple assets. ${ }^{2}$ Even though common information is less valuable than firm-specific information, investors still acquire it because its high demand reduces its acquisition cost. The clustered use of common information adds common shocks to related stocks and contributes to excess stock return comovement. Empirical evidence is consistent with the information choice argument as an explanation for stock return comovement (See Brockman et al. (2010) and Hameed et al. (2015) for recent examples).

Our study examines whether foreign institutional investors exert influence on firms' information environment through their acquisition of firm-specific information, thereby mitigating excess stock return comovement. Admittedly, establishing a causal link from institutional ownership to stock return comovement is a difficult task, in particular because we do not directly observe investors' information choices with respect to firm-specific versus common information. We use two observable firm-level characteristics of institutional ownership to identify institutions' information choices and test their impact on stock return comovement. First, as investors' information choices depend on their ability to bear the fixed cost of producing firm-specific information (Veldkamp, 2006), we argue that the size of an institution's stakeholdings enhances its ability to produce firm-specific information. In particular, high-stake institutions maintain a comparative advantage over low-stake institutions in producing firm-specific information (Bushee and Goodman, 2007; Ali et al., 2008). The fact that information has an increasing return to scale implies that these high-stake institutions can effectively spread the fixed cost of producing firm-specific information over their holdings. In addition, high-stake institutions can effectively reduce competition among indirectly informed investors, and thus fully extract their trading profits from firm-specific information (Admati and Pfleiderer, 1988). ${ }^{3}$

Second, as investors' choices may depend on the composition of their portfolio and their ability to process information, we argue that domestic institutions may contribute more to excess stock return comovements than foreign institutions. Studies find that 
foreign institutions invest in selected local stocks that are larger and more transparent (Kang and Stulz, 1997), have greater global exposure (Covrig et al., 2006; Ferreira and Matos, 2008), and have better corporate governance (Leuz et al., 2009). In contrast, domestic institutions hold a wide array of local stocks (Covrig et al., 2006). Thus, domestic institutions can rely more on common information useful for valuing their diverse local holdings to economize on the cost of information production. In addition, foreign institutions from well-developed countries are endowed with more value-relevant information. Albuquerque et al. (2009) show that U.S. institutions have better access to global private information, which gives them an advantage in interpreting public information. Bailey et al. (2007) show that foreign institutional investors in general have superior information processing capabilities to generate private firm-specific information in conjunction with public information.

We use firm-level institutional shareholdings of international stocks from the Thomson One Ownership Module for the period of 1997-2006. Our sample consists of 11,016 firms which comprise a total of 54,730 firm-year observations from 40 countries. We make the following predictions. First, we predict that foreign institutions from countries with strong investor protection play a more important role in enhancing firm-specific information flow in the market than domestic institutions. Second, we predict that high-stake institutions are more likely to produce firm-specific information than low-stake institutions.

Our results can be summarized as follows. First, we find that stock return comovements are negatively related to shareholdings of foreign institutions but positively related to shareholdings of domestic institutions. Among foreign institutions, those from countries with strong investor protection (e.g., common-law countries or countries for which the anti-self-dealing index is high) facilitate firm-specific information flow, thereby reducing stock return comovement, to a greater extent, than those from countries with weak investor protection (civil-law countries or countries for which the anti-self-dealing index is low). Second, we find that high-stake institutions, foreign and domestic alike, reduce stock return comovement, while low-stake institutions increase stock return comovement. This is consistent with the view that high-stake institutions have an advantage over low-stake institutions in coping with the fixed costs of producing firm-specific information. Moreover, we examine whether investor protection in the country where a firm is located influences the role that foreign institutions play in reducing stock return comovement. We find that high-stake foreign institutions from common-law countries are the main driver in facilitating firm-specific information flow for firms located in civil-law countries.

Finally, we perform a variety of tests designed to address endogeneity issues concerning institutional ownership and conduct additional tests to address an alternative monitoring explanation. Ferreira and Matos (2008) and Chen et al. (2007) show that long-term independent foreign institutional investors play an important monitoring role, which may improve a firm's firm-specific information flow into stock prices. ${ }^{4}$ However, we find no evidence that long-term independent institutional investors reduce stock return comovement. Although we cannot completely exclude the monitoring explanation, our evidence suggests that the informational role played by institutional investors is important and different from the monitoring role.

Our study contributes to the literature in the following ways. First, our study provides systematic evidence that foreign institutional investors play an important informational role in facilitating firm-specific information flow in the market. We achieve this objective 
by inferring information choices by institutional investors based on their institutional shareholding characteristics. Second, we explore the interaction between firm-level foreign institutional ownership and country-level governance, and find that foreign institutions from countries with strong investor protection are superior to domestic institutions in facilitating firm-specific information flow in the market, particularly for firms from countries with weak investor protection. This finding provides useful insights into the impact of investor protection on the informational role of foreign institutional investors in the global financial markets.

The remainder of this paper proceeds as follows. Section "Data, variables and model specification" describes the data and variable measurement, specifies empirical models, and presents descriptive statistics. Section "Main empirical tests" reports the results of our main empirical tests. Section "Endogeneity issue" performs a variety of tests for endogeneity and establishes a causal relation between stock return comovement and shareholdings by different institutions with differing characteristics. Section "Robustness check" conducts robustness tests. The final section concludes.

\section{Data, variables and model specification \\ Data}

The institutional shareholdings data are drawn from the Thomson One Ownership Module. This database contains global shareholding information, including data on ownership of equities from over 70 countries and institutional portfolios from over 27 countries. ${ }^{5}$ The institutions covered in the database are professional money managers such as mutual funds, hedge funds, pension funds, bank trusts, and insurance companies. We use institutional ownership data for the period from 1997 to 2006 and extract financial statements data from Worldscope. We collect the following data items from Datastream: the weekly return index $(R I)$, the market return index $(M I)$, the exchange rate, the share price $(P)$, the number of shares outstanding $(N O S H)$, and the trading volume $(V O)$. These data are necessary to compute firm-specific return comovement, trading turnover, and future returns for individual stocks.

We combine the Worldscope/Datastream sample with the institutional ownership data from the Thomson One Ownership Module at the end of each year using SEDOL codes. ${ }^{6}$ We first exclude financial firms (SIC 6000-6999). Similar to Morck et al. (2000) and Jin and Myers (2006), we require all financial data to be available from Worldscope and weekly stock return data from Datastream to be available for at least 26 weeks. We require the total assets for each firm to be greater than $\$ 100$ million. We obtain a final sample of 11,016 non-U.S. firms which comprise a total of 54,730 firm-year observations from 40 countries over the sample period of 1997-2006. Table 1 provides the distribution of our sample firms by country.

\section{Measuring institutional ownership}

We define total institutional ownership (IO_TOTAL) for each stock as the number of shares held by all institutions divided by the total number of shares outstanding at the end of each calendar year. Following Gompers and Metrick (2001), we set IO_TOTAL to zero if a stock is not held by any institution as recorded in the Thomson One Ownership Module. We also exclude observations with IO_TOTAL greater than $100 \%$. We then 
Table 1 Summary statistics by country

\begin{tabular}{|c|c|c|c|c|c|c|}
\hline Country and region & No. of obs. & Comovement & IO_TOTAL & 10_DOM & IO_FOR & Common law \\
\hline Argentina & 221 & -0.6570 & 0.0188 & 0.0000 & 0.0188 & 0 \\
\hline Australia & 2339 & -1.7074 & 0.0864 & 0.0472 & 0.0392 & 1 \\
\hline Austria & 304 & -1.4772 & 0.0923 & 0.0224 & 0.0699 & 0 \\
\hline Belgium & 465 & -1.4220 & 0.1057 & 0.0620 & 0.0438 & 0 \\
\hline Brazil & 474 & -1.1107 & 0.0670 & 0.0000 & 0.0670 & 0 \\
\hline Canada & 2864 & -1.7022 & 0.2292 & 0.1806 & 0.0486 & 1 \\
\hline Chile & 382 & -1.1644 & 0.0059 & 0.0000 & 0.0059 & 0 \\
\hline Chinese mainland & 414 & -1.0993 & 0.2356 & 0.0103 & 0.2253 & 0 \\
\hline Denmark & 510 & -1.4868 & 0.0960 & 0.0459 & 0.0501 & 0 \\
\hline Finland & 549 & -1.4146 & 0.1834 & 0.0719 & 0.1115 & 0 \\
\hline France & 2898 & -1.4413 & 0.1245 & 0.0781 & 0.0464 & 0 \\
\hline Germany & 2256 & -1.4403 & 0.1443 & 0.0758 & 0.0685 & 0 \\
\hline Greece & 996 & -0.6872 & 0.0788 & 0.0600 & 0.0188 & 0 \\
\hline Chinese Hong Kong & 2227 & -1.3552 & 0.0689 & 0.0070 & 0.0619 & 1 \\
\hline Hungary & 109 & -1.0399 & 0.1393 & 0.0000 & 0.1393 & 0 \\
\hline India & 1358 & -0.7188 & 0.1104 & 0.0715 & 0.0389 & 1 \\
\hline Indonesia & 548 & -0.8818 & 0.0660 & 0.0000 & 0.0660 & 0 \\
\hline Ireland & 179 & -1.4733 & 0.1379 & 0.0066 & 0.1313 & 1 \\
\hline Israel & 497 & -1.1497 & 0.0822 & 0.0020 & 0.0802 & 1 \\
\hline Italy & 1032 & -1.1080 & 0.0900 & 0.0383 & 0.0517 & 0 \\
\hline Japan & 16,351 & -1.1069 & 0.0404 & 0.0229 & 0.0175 & 0 \\
\hline Korea (South) & 1892 & -1.0690 & 0.0602 & 0.0000 & 0.0602 & 0 \\
\hline Malaysia & 2059 & -0.9885 & 0.0170 & 0.0000 & 0.0170 & 1 \\
\hline Netherlands & 224 & -1.3906 & 0.2854 & 0.0600 & 0.2253 & 0 \\
\hline New Zealand & 287 & -1.4265 & 0.0552 & 0.0000 & 0.0552 & 1 \\
\hline Norway & 429 & -1.1294 & 0.1823 & 0.1111 & 0.0713 & 0 \\
\hline Pakistan & 109 & -0.1594 & 0.0297 & 0.0000 & 0.0297 & 1 \\
\hline Philippines & 286 & -1.0874 & 0.0340 & 0.0000 & 0.0340 & 0 \\
\hline Poland & 263 & -1.0660 & 0.1402 & 0.0678 & 0.0724 & 0 \\
\hline Portugal & 254 & -1.2946 & 0.1196 & 0.0722 & 0.0474 & 0 \\
\hline Russian Federation & 105 & -0.6963 & 0.0410 & 0.0000 & 0.0410 & 0 \\
\hline Singapore & 1250 & -1.1749 & 0.0562 & 0.0154 & 0.0408 & 1 \\
\hline South Africa & 863 & -1.4400 & 0.1207 & 0.0923 & 0.0284 & 1 \\
\hline Spain & 614 & -1.1063 & 0.1531 & 0.0823 & 0.0708 & 0 \\
\hline Sweden & 1010 & -1.1493 & 0.2679 & 0.1878 & 0.0801 & 0 \\
\hline Switzerland & 932 & -1.3910 & 0.1728 & 0.0752 & 0.0977 & 0 \\
\hline Chinese Taiwan & 1656 & -0.9409 & 0.0405 & 0.0001 & 0.0404 & 0 \\
\hline Thailand & 881 & -1.0711 & 0.0503 & 0.0000 & 0.0503 & 1 \\
\hline Turkey & 148 & -0.4251 & 0.2240 & 0.0000 & 0.2240 & 0 \\
\hline United Kingdom & 4495 & -1.6473 & 0.1688 & 0.1339 & 0.0349 & 1 \\
\hline
\end{tabular}

Notes. This table shows the number of observations, the average of return comovement and institutional ownership by country, and the country level variables of investor protection 
classify total institutional ownership into two categories according to country origins and size of shareholdings.

First, we classify institutions into foreign and domestic institutions based on the location of their headquarters, and then further partition foreign institutions depending on whether they originate from countries with strong or weak investor protection. Specifically, for each stock, domestic institutional ownership $\left(I O \_D O M\right)$ is the sum of shareholdings of all institutions headquartered in the same country where a stock is listed divided by its total number of shares outstanding. Foreign institutional ownership (IO_FOR) is the sum of shareholdings of all institutions headquartered in foreign countries, i.e., countries different from the country in which a stock is listed, divided by its total number of shares outstanding.

We further measure country-level corporate governance by its legal origins from La Porta et al. (1998) and the anti-self-dealing index from Djankov et al. (2008). In particular, countries with strong investor protection are either common-law countries or countries for which the anti-self-dealing index is high, whereas countries with weak investor protection are either civil-law countries or countries with a low anti-self-dealing index. We create four additional variables of interest: IO_FOR_COMMON (IO_FOR_CIVIL) is the sum of the shareholdings of all institutions headquartered in common-law (civil-law) countries divided by the total number of shares outstanding. IO_FOR_HASD $\left(I O_{-} F O R_{-} L A S D\right)$ is the sum of the shareholdings of all institutions headquartered in countries with above (below) median anti-self-dealing index scores divided by the total number of shares outstanding.

Second, we divide domestic and foreign institutions (from countries with both strong and weak investor protection) based on their size of stakeholdings. Following Ali et al. (2008), we use the 5\% cutoff point to identify high-stake institutions. Bushee (1998) also classifies institutions with stakeholdings above $5 \%$ as dedicated investors. Specifically, we define high-stake institutional ownership $\left(I O \_H I G H\right)$ as the sum of the shareholdings by institutions with more than $5 \%$ shares in a stock divided by its total number of shares outstanding. Similarly, we use the $1 \%$ cutoff point and define low-stake institutional ownership (IO_LOW) as the sum of the shareholdings by institutions with less than $1 \%$ shares in a stock divided by its total number of shares outstanding. We leave out medium-level institutional ownership ranging from $1 \%$ to $5 \%$.

\section{Measuring stock return comovement}

To measure stock return comovement, we estimate the following augmented market model using weekly return data for each stock in each year:

$$
\begin{aligned}
r_{i, t}=\alpha_{i} & +\beta_{1, t} r_{m, i, t-1}+\beta_{2, t}\left(r_{u s, t-1}+e_{i, t-1}\right)+\beta_{3, t} r_{m, i, t}+\beta_{4, t}\left(r_{u s, t}+e_{i, t}\right) \\
& +\beta_{5, t} r_{m, i, t+1}+\beta_{6, t}\left(r_{u s, t+1}+e_{i, t+1}\right)+\varepsilon_{i, t},
\end{aligned}
$$

where, for stock $i$ and year $t, r_{i, t}$ refers to weekly return; $r_{m, i, t}$ represents the valueweighted domestic weekly market index return in country $j ; r_{u s, t}$ is the value-weighted U.S. weekly market index return (a proxy for the global market factor); $e_{i, t}$ denotes the weekly change in country $i$ 's exchange rate per U.S. dollar; and $\varepsilon_{i, t}$ represents unspecified factors. The expression $r_{u s, t}+e_{i, t}$ translates U.S. stock market returns into local currency units. We include lead and lag terms for the market index returns to alleviate potential bias associated 
with nonsynchronous trading (Dimson, 1979). ${ }^{7}$ In estimating Eq. (1), we exclude stocks that trade for fewer than 26 weeks during a year.

Let $\sigma_{i}^{2}$ and $\sigma_{i e}^{2}$ denote the total return variation and the firm-specific return variation, respectively, of Eq. (1). Then the common return variation is measured by $\sigma_{i}{ }^{2}-\sigma_{i e}{ }^{2}$. For each firm in the sample, we compute the relative common return variation for each stock using the ratio of the common return variation to the total return variation, that is $\left(\sigma_{i}{ }^{2}-\sigma_{i e}{ }^{2}\right) / \sigma_{i}{ }^{2}$. Note here that $R_{i}{ }^{2}$ of Eq. (1) is equal to this ratio, while $1-R_{i}^{2}$ of Eq. (1) is equal to $\sigma_{i e}{ }^{2} / \sigma_{i}{ }^{2}$. Similar to other $R^{2}$-based studies (Piotroski and Roulstone 2004; Jin and Myers 2006), we then obtain our measure of stock return comovement for firm $i$, denoted by Comovement $t_{i}$ in each year, as:

$$
\text { Comovement }_{i}=\ln \left[R_{i}^{2} /\left(1-R_{i}^{2}\right)\right]=\ln \left[\left({\sigma_{i}}^{2}-{\sigma_{i e}}^{2}\right) / \sigma_{i e}{ }^{2}\right] .
$$

The logarithmic transformation is applied to circumvent the bounded nature of $R_{i}{ }^{2}$ within $[0,1]$. By construction, high values of Comovement mean a higher level of common return variation relative to firm-specific return variation.

\section{Empirical specification}

To test our predictions on the impact of foreign institutional ownership on stock return comovement or synchronicity, we specify the following baseline regression model:

$$
\begin{aligned}
\text { Comovement }_{i, t}= & \alpha_{0}+\alpha_{1} I_{i, t-1}+\alpha_{2} \text { SIZE }_{i, t-1}+\alpha_{3} \text { Comovment }_{i, t-1}+\alpha_{4} M B_{i, t-1} \\
& +\alpha_{5} L E V_{i, t-1}+\alpha_{6} \text { ACCR }_{i, t}+\alpha_{7} \text { ROA }_{i, t}+\alpha_{8} \text { DIVERS }_{i, t} \\
& +\alpha_{9} H E R F_{i, t}+\alpha_{10} \text { NIND }_{i, t}+\alpha_{11} N A F_{i, t}+\alpha_{12} \text { TURN }_{i, t} \\
& +(\text { Year }, \text { Industry }, \text { Country Dummies })+\varepsilon
\end{aligned}
$$

where, for firm $i$ and year $t$ (or $t-1$ ), Comovement denotes stock return comovement as defined in Eq. (2); and our test variable, $I O$, represents different classifications of institutional ownership.

To isolate the effect of institutional ownership on Comovement from the effect of other firm- and industry-level factors, we include in Eq. (3) a total of eleven firm- and industry-level control variables that are known to influence Comovement, that is: (i) firm size measured by the natural log of market capitalization (SIZE); (ii) the lagged comovement as a control for past comovement; (iii) the ratio of market value of equity to the book value of equity at the end of the fiscal year $(M B)$; (iv) financial leverage measured by the book value of long-term debt scaled by the sum of market value of equity and book value of long-term debt at the end of the fiscal year ( $L E V)$; (v) the ratio of absolute total accruals to beginning-of-year operating cash flows $(A C C R)$; (vi) the income before extraordinary items divided by the beginning-of-fiscal year total assets ( $R O A)$; (vii) firm-level diversification measured by the number of business segments (DIVERS); (viii) the revenue-based Herfindahl index that captures industry-level concentration (HERF); (ix) the natural log of the number of firms in each industry (NIND); (x) the natural log of number of analysts following a firm per year (NAF); and (xi) trading volume measured by the average monthly trading turnover (TURN). We include Year, Industry, and Country dummies to control for year, industry, and country fixed effects, respectively. Appendix A provides detailed definitions of all the variables included in Eq. (3). 


\section{Descriptive statistics}

Table 1 shows that the total number of firm-year observations for non-U.S. firms varies from a minimum of 105 in Russia to a maximum of 16,351 in Japan. Stock return comovement on average is lower in common-law countries and regions (e.g., Australia, Canada, Chinese Hong Kong, Ireland, New Zealand, South Africa, and the U.K.), while stock return comovement is higher in civil-law countries (e.g., Greece, Italy, and Turkey) and emerging market countries (e.g., Argentina and the Philippines).

Table 2 presents descriptive statistics for the variables used in our regression analysis. We winsorize continuous financial variables and test variables at the $1 \%$ and $99 \%$ levels to mitigate the potential effect of outliers. The mean of total institutional ownership (IO_TOTAL) is $9.42 \%$ for non-U.S. stocks. When we classify institutional ownership by an institution's country of origin, we find that, on average, domestic institutional ownership (5.16\%) exceeds foreign institutional ownership (4.26\%), foreign institutional ownership from common-law countries (3.15\%) exceeds foreign institutional ownership from civil-law countries $(1.10 \%)$, and foreign institutional ownership from countries with high anti-self-dealing index scores (2.56\%) exceeds foreign institutional ownership from countries with low anti-self-dealing index scores (1.69\%). Given that ownership is highly concentrated in non-U.S. markets and the free float for international stocks is lower (55.53\%), the average size of foreign institutional ownership allows foreign institutions to exert a significant influence on domestic stocks.

When we classify domestic and foreign institutional ownership by each institution's stakeholding size, we find that low-stake institutional ownership is, on average, greater than that of high-stake institutional ownership for both domestic and foreign institutions. On average, low-stake domestic institutions hold $1.95 \%$ of all shares, and high-stake domestic institutions hold $0.79 \%$ of all shares, while low-stake foreign institutions hold $1.29 \%$ of all shares and high-stake foreign institutions hold $0.67 \%$ of all shares.

Table 2 shows that the mean and median of Comovement are -1.2416 and -1.2330 , respectively. Note here that the mean Comovement of -1.2416 for our international sample is larger than the mean of -2.731 for the U.S. sample of Ferreira and Laux (2007), suggesting that stock prices co-move more with common factors for non-U.S. firms than for U.S. firms. The standard deviation of Comovement is relatively large at 0.8791, suggesting a wide variation of our Comovement measure across firms.

\section{Main empirical tests}

In this section, we test our predictions on the impact of foreign institutions with different characteristics on the relative flow of firm-specific information versus common information, as captured by stock return comovement.

\section{Domestic versus foreign institutions}

We predict that shareholdings by foreign institutions facilitate the incorporation of firm-specific information into stock price, and thus reduce stock return comovement, to a greater extent, than shareholdings by domestic institutions. To test this prediction, we start with our baseline regression in Eq. (3), using total institutional ownership (IO_TOTAL) as the test variable, so that our results can be compared with the U.S. study. Table 3 reports the results of various regressions in Eq. (3). Throughout the paper, all reported $t$-values are on an adjusted basis using robust standard errors 
Table 2 Descriptive statistics

\begin{tabular}{|c|c|c|c|c|c|c|}
\hline & No. of obs. & Mean & Std. Dev. & 5th Pctl. & Median & 95th Pctl. \\
\hline \multicolumn{7}{|l|}{ Institutional ownership variables } \\
\hline 10_TOTAL $L_{t-1}$ & 54,730 & 0.0942 & 0.1324 & 0.0004 & 0.0405 & 0.3669 \\
\hline $10 \_D O M_{t-1}$ & 54,730 & 0.0516 & 0.0929 & 0.0000 & 0.0099 & 0.2350 \\
\hline $1 O_{-} F O R_{t-1}$ & 54,730 & 0.0426 & 0.0859 & 0.0000 & 0.0082 & 0.2061 \\
\hline IO_FOR_COMMON $N_{t-1}$ & 54,730 & 0.0315 & 0.0718 & 0.0000 & 0.0045 & 0.1573 \\
\hline IO_FOR_CIVIL $L_{t-1}$ & 54,730 & 0.0110 & 0.0305 & 0.0000 & 0.0003 & 0.1586 \\
\hline IO_FOR_HASD $D_{t-1}$ & 54,730 & 0.0256 & 0.0483 & 0.0000 & 0.0080 & 0.0887 \\
\hline IO_FOR_LASD $D_{t-1}$ & 54,730 & 0.0169 & 0.0279 & 0.0000 & 0.0042 & 0.0742 \\
\hline IO_DOM_HIGH $H_{t-1}$ & 54,730 & 0.0079 & 0.0427 & 0.0000 & 0.0000 & 0.0562 \\
\hline 10_DOM_LOW $W_{t-1}$ & 54,730 & 0.0195 & 0.0388 & 0.0000 & 0.0048 & 0.0944 \\
\hline IO_FOR_HIGH & 54,730 & 0.0067 & 0.0394 & 0.0000 & 0.0000 & 0.0503 \\
\hline IO_FOR_LOW & 54,730 & 0.0129 & 0.0263 & 0.0000 & 0.0029 & 0.0616 \\
\hline IO_FOR_COMMON_HIGH $H_{t-1}$ & 54,730 & 0.0012 & 0.0155 & 0.0000 & 0.0000 & 0.0000 \\
\hline IO_FOR_COMMON_LOW $W_{t-1}$ & 54,730 & 0.0066 & 0.0165 & 0.0000 & 0.0001 & 0.0343 \\
\hline IO_FOR_CIVIL_HIGH $H_{t-1}$ & 54,730 & 0.0068 & 0.0398 & 0.0000 & 0.0000 & 0.0510 \\
\hline IO_FOR_CIVIL_LOW $W_{t-1}$ & 54,730 & 0.0141 & 0.0285 & 0.0000 & 0.0033 & 0.0676 \\
\hline IO_FOR_HASD_HIGH $H_{t-1}$ & 54,730 & 0.0010 & 0.0145 & 0.0000 & 0.0000 & 0.0000 \\
\hline IO_FOR_HASD_LOW & 54,730 & 0.0053 & 0.0139 & 0.0000 & 0.0000 & 0.0278 \\
\hline IO_FOR_LASD_HIGH $H_{t-1}$ & 54,730 & 0.0942 & 0.1324 & 0.0004 & 0.0405 & 0.3669 \\
\hline IO_FOR_LASD_LOW $W_{t-1}$ & 54,730 & 0.0516 & 0.0929 & 0.0000 & 0.0099 & 0.2350 \\
\hline \multicolumn{7}{|c|}{ Return Comovement as test variable } \\
\hline Comovement $t_{t}$ & 54,730 & -1.2416 & 0.8791 & -2.7325 & -1.2330 & 0.1928 \\
\hline \multicolumn{7}{|l|}{ Firm-specific control variables } \\
\hline$S I Z E_{t-1}$ & 54,730 & 9.8190 & 1.7425 & 7.2399 & 9.6344 & 13.1018 \\
\hline Comovement $_{t-1}$ & 54,730 & -1.2798 & 0.8795 & -2.7623 & -1.2768 & 0.1599 \\
\hline$M B_{t-1}$ & 54,730 & 2.2286 & 2.8534 & 0.3714 & 1.3928 & 6.8754 \\
\hline$L E V_{t-1}$ & 54,730 & 0.1232 & 0.1322 & 0.0000 & 0.0843 & 0.3920 \\
\hline$A C C R_{t}$ & 54,730 & 0.9351 & 1.7425 & 0.0679 & 0.5772 & 2.7459 \\
\hline$R O A_{t}$ & 54,730 & 0.1307 & 0.1063 & 0.0197 & 0.1077 & 0.3129 \\
\hline DIVERS $s_{t}$ & 54,730 & 3.8330 & 2.0233 & 1.0000 & 3.0000 & 8.0000 \\
\hline$H E R F_{t}$ & 54,730 & 0.2456 & 0.2357 & 0.0295 & 0.1590 & 0.8073 \\
\hline$N I N D_{t}$ & 54,730 & 7.0657 & 1.0714 & 5.1180 & 7.1824 & 8.3311 \\
\hline$N A F_{t}$ & 54,730 & 1.2639 & 1.0838 & 0.0000 & 1.0986 & 3.1781 \\
\hline$T_{U R N_{t}}$ & 54,730 & 0.0797 & 0.1342 & 0.0029 & 0.0353 & 0.3217 \\
\hline$S I Z E_{t}$ & 54,690 & 9.9209 & 1.7554 & 7.3093 & 9.7335 & 13.2116 \\
\hline$M B_{t}$ & 54,689 & 2.9010 & 62.6531 & 0.3857 & 1.4056 & 6.5020 \\
\hline$D P_{t}$ & 54,730 & 0.0240 & 0.0866 & 0.0000 & 0.0147 & 0.0761 \\
\hline$P R / C E_{t}$ & 54,730 & 1.5820 & 2.2509 & -2.1483 & 1.5698 & 5.7461 \\
\hline$V O L A_{t}$ & 53,399 & 0.0695 & 0.1362 & 0.0024 & 0.0250 & 0.2973 \\
\hline$A G E_{t}$ & 54,730 & 4.8488 & 0.7569 & 3.4340 & 4.9416 & 5.9636 \\
\hline$R E T_{t-2, t}$ & 54,724 & 0.0322 & 0.2346 & -0.3092 & 0.0133 & 0.4421 \\
\hline$R E T_{t-12, t-3}$ & 54,220 & 0.1646 & 0.5535 & -0.4893 & 0.0754 & 1.1431 \\
\hline FSALE & 54,730 & 0.2007 & 0.4859 & 0.0000 & 0.0000 & 0.8779 \\
\hline
\end{tabular}

Notes. This table reports descriptive statistics. To be included in the sample, a firm must have stock returns and trading volume in the Datastream database and assets and other financial data in the Worldscope database for the period 1997-2006, as well as lagged financial data. The institutional ownership data are obtained from the Thomson One Ownership Module database. The exact definitions of variables are provided in Appendix A 
Table 3 Comovement and domestic versus foreign institutions

\begin{tabular}{|c|c|c|c|c|}
\hline & (1) & (2) & (3) & (4) \\
\hline \multirow[t]{2}{*}{ IO_TOTAL } & 0.0371 & & & \\
\hline & $(1.16)$ & & & \\
\hline \multirow[t]{2}{*}{ 10_DOM $M_{t-1}$} & & $0.0997^{* *}$ & $0.0862^{*}$ & $0.0902^{* *}$ \\
\hline & & $(2.25)$ & $(1.96)$ & $(2.05)$ \\
\hline \multirow[t]{2}{*}{$10 \_F O R_{t-1}$} & & $-0.0279^{* *}$ & & \\
\hline & & $(-1.98)$ & & \\
\hline \multirow[t]{2}{*}{ IO_FOR_COMMON } & & & $-0.2170^{* * *}$ & \\
\hline & & & $(-4.05)$ & \\
\hline \multirow[t]{2}{*}{ IO_FOR_CIVIL $L_{t-1}$} & & & $0.7650^{* * *}$ & \\
\hline & & & $(6.06)$ & \\
\hline \multirow[t]{2}{*}{ IO_FOR_HASD $D_{t-1}$} & & & & $-0.1810^{* * *}$ \\
\hline & & & & $(-3.50)$ \\
\hline \multirow[t]{2}{*}{ 10_FOR_LASD $D_{t-1}$} & & & & $0.8150^{* * *}$ \\
\hline & & & & $(5.62)$ \\
\hline \multirow[t]{2}{*}{$S I Z E_{t-1}$} & $0.1132^{* * *}$ & $0.1131^{* * *}$ & $0.1132^{* * *}$ & $0.1131^{* * *}$ \\
\hline & (32.19) & (32.24) & $(32.31)$ & $(32.23)$ \\
\hline \multirow[t]{2}{*}{ Comovement $_{t-1}$} & $0.2251^{* * *}$ & $0.2252^{* * *}$ & $0.2243^{* * *}$ & $0.2242^{* * *}$ \\
\hline & $(47.37)$ & $(47.34)$ & $(47.21)$ & $(47.20)$ \\
\hline \multirow[t]{2}{*}{$M B_{t-1}$} & 0.0015 & 0.0016 & 0.0015 & 0.0015 \\
\hline & $(1.07)$ & $(1.14)$ & $(1.10)$ & $(1.10)$ \\
\hline \multirow[t]{2}{*}{$L E V_{t-1}$} & $0.1163^{* * *}$ & $0.1152^{* * *}$ & $0.115^{* * *}$ & $0.1142^{* * *}$ \\
\hline & $(4.04)$ & (3.99) & $(3.98)$ & $(3.95)$ \\
\hline \multirow[t]{2}{*}{$A C C R_{t}$} & -0.0001 & -0.0001 & -0.0000 & -0.0001 \\
\hline & $(-0.036)$ & $(-0.042)$ & $(-0.012)$ & $(-0.03)$ \\
\hline \multirow[t]{2}{*}{$R O A_{t}$} & $-0.2223^{* * *}$ & $-0.220^{* * *}$ & $-0.2213^{* * *}$ & $-0.2222^{* * *}$ \\
\hline & $(-6.82)$ & $(-6.78)$ & $(-6.80)$ & $(-6.81)$ \\
\hline \multirow[t]{2}{*}{ DIVERS ${ }_{t}$} & $0.0168^{* * *}$ & $0.0168^{* * *}$ & $0.0168^{* * *}$ & $0.0168^{* * *}$ \\
\hline & $(8.51)$ & $(8.48)$ & $(8.50)$ & $(8.50)$ \\
\hline \multirow[t]{2}{*}{$\operatorname{HERF}_{t}$} & -0.0056 & -0.0057 & -0.0049 & -0.0052 \\
\hline & $(-0.26)$ & $(-0.26)$ & $(-0.22)$ & $(-0.24)$ \\
\hline \multirow[t]{2}{*}{$N I N D_{t}$} & $-0.1291^{* * *}$ & $-0.1302^{* * *}$ & $-0.1241^{* * *}$ & $-0.1250^{* * *}$ \\
\hline & $(-6.08)$ & $(-6.13)$ & $(-5.87)$ & $(-5.93)$ \\
\hline \multirow[t]{2}{*}{$N A F_{t}$} & $0.0573^{* * *}$ & $0.0577^{* * *}$ & $0.0569^{* * *}$ & $0.05732^{* * *}$ \\
\hline & $(11.06)$ & $(11.15)$ & $(11.02)$ & (11.08) \\
\hline \multirow[t]{2}{*}{$T_{U} R_{t}$} & $0.3741^{* * *}$ & $0.3742^{* * *}$ & $0.3692^{* * *}$ & $0.3693^{* * *}$ \\
\hline & (13.38) & (13.34) & (13.18) & $(13.21)$ \\
\hline \multirow[t]{2}{*}{ Intercept } & $-1.2701^{* * *}$ & $-1.2672^{* * *}$ & $-1.3433^{* * *}$ & $-1.3362^{* * *}$ \\
\hline & $(-6.02)$ & $(-6.01)$ & $(-5.98)$ & $(-5.91)$ \\
\hline No. of obs. & 54,730 & 54,730 & 54,730 & 54,730 \\
\hline Adjusted $R^{2}$ & 0.342 & 0.342 & 0.342 & 0.342 \\
\hline
\end{tabular}

Notes. This table reports the regression analysis of stock return comovement on domestic versus foreign institutional ownership. The sample consists of 54,730 firm-year observations drawn from 40 countries for 1997-2006. The dependent variable is Comovement $t_{t}$. The coefficients and the test statistics are based on the regression model in Eq. (3). The $t$-statistics, reported in parentheses, are based on robust standard errors corrected for firm-level clustering. Year, industry and country dummies are included. Here ${ }^{* * *}, *^{*}$, and ${ }^{*}$ indicate significance at the $1 \%, 5 \%$, and $10 \%$ levels, respectively. All variables are defined in Appendix $A$ 
corrected for firm-level clustering (Petersen, 2009). As shown in column 1, the coefficient of total institutional ownership, IO_TOTAL, is insignificant. This is consistent with the U.S. findings of Piotroski and Roulstone (2004) that the association between total institutional ownership and stock return comovement is ambiguous.

In Table 3, we include a number of control variables that are used in previous research. Consistent with the U.S. evidence of Piotroski and Roulstone (2004) and Ferreira and Laux (2007) and the non-U.S. international evidence of Fernandes and Ferreira (2008), we find that the coefficients of SIZE,LEV, DIVERS, NAF and TURN are all positive and significant at the $1 \%$ level, and the coefficients of ROA and NIND are negative and significant at the $1 \%$ level. The coefficients of NAF are positive and significant at the $1 \%$ level, confirming that analysts play a role in facilitating the incorporation of common information into stock price via inter-industry information transmission (Piotroski and Roulstone, 2004). The coefficients of $M B, A C C R$, and $H E R F$ are insignificant across all columns in Table 3. Note that the coefficients of Comovement $t_{t-1}$ are positive and significant at the $1 \%$ level, suggesting that stock return comovement persists over time.

To examine our predictions on the effect of foreign and domestic institutional ownership on stock return comovement, we re-estimate Eq. (3) after partitioning total institutional ownership into domestic and foreign institutional ownership (i.e., by including $I O \_D O M$ and IO_FOR in lieu of IO_TOTAL). As shown in column 2 of Table 3, the coefficient of $I O \_D O M$ is positive and significant at the $5 \%$ level, while the coefficient of $I O \_F O R$ is negative and significant at the $5 \%$ level. This lends support to our first prediction that foreign institutions contribute more to the incorporation of firm-specific information into stock price than domestic institutions. This evidence is consistent with the view that domestic institutions rely more on common information when making their investment decisions compared with foreign institutions.

Next, we investigate whether the legal origin of a foreign institution's home country matters. In doing so, we classify a foreign institution based on whether its headquarters are domiciled in a common-law (civil-law) country, or whether they originate in a country with higher (lower) anti-self-dealing index scores. We find that the coefficient of $I O \_D O M$ remains positive and significant. The coefficient of IO_FOR_COMMON is significant at the $1 \%$ level, with an expected negative sign, whereas the coefficient of IO_FOR_CIVIL is significant at the $1 \%$ level, with a positive sign. Similarly, in column 3, the coefficient of $I O \_F O R_{-} H A S D$ is significant at the $1 \%$ level, with an expected negative sign, while the coefficient of $I_{-}$FOR_LASD, is significant at the $1 \%$ level, with an expected positive sign. This indicates that foreign institutions in countries with strong investor protection contribute significantly to the incorporation of firm-specific information into stock price.

We further evaluate the economic impact of institutional ownership on $R^{2}$ using coefficient estimates reported in column 3 of Table 3. The regression estimates the impact on Comovement, which is the transformed $R^{2}$. We calculate the impact on $R^{2}$ for our augmented market model in Eq. (1) by inverting Eq. (2). The coefficients of IO_DOM, IO_FOR_COMMON and IO_FOR_CIVIL indicate that a ten-percent increase in ownership is associated with a change of $R^{2}$ by $0.15 \%,-0.38 \%$ and $1.30 \%$, respectively. The economic impact of IO_FOR_COMMON on $R^{2}$ is nontrivial.

Overall, our results in Table 3 strongly support our first prediction, suggesting that foreign institutions differ from domestic institutions in their quest for and capability of 
producing firm-specific information. In particular, our results are consistent with the view that foreign institutional investors from countries with strong investor protection are more effective in facilitating the flow of firm-specific information in the market, thereby lowering stock return comovement. Foreign institutions from common-law countries (especially U.S. institutions) are endowed with global private information, which Albuquerque et al. (2009) use to account for the fact that U.S. institutional investors have superior knowledge about U.S. industrial production and monetary policies, as well as global trends in market demands and technological advances. Such knowledge of global factors can give U.S. institutions an advantage in processing public information of local stocks into valuation-relevant private information. Overall, our results suggest that foreign institutions from common-law countries rely more on firm-specific information, and thus contribute more to the incorporation of firm-specific information into stock price, while foreign institutions from civil-law countries rely more on common information, and thus contribute more to the incorporation of common information into stock price.

\section{High-stake versus low-stake institutions}

We predict that the size of institutional stakeholdings is inversely associated with stock return comovement. To test this prediction, we further partition domestic and foreign institutional ownerships (i.e., $I O \_D O M$ and $I O \_F O R$ ) according to the size of an institution's stakeholding, that is: $I O \_D O M \_H I G H$ versus $I O \_D O M \_L O W$ and $I O \_F O R \_H I G H$ versus $I O \_F O R \_L O W$, respectively. We then estimate our base line regression in Eq. (3) using these refined variables, that is: $I O \_D O M \_H I G H$ and $I O \_D O M \_L O W$ in place of $I O \_D O M$; and $I O \_F O R \_H I G H$ and $I_{-} O_{-} F O R_{-} L O W$ in place of $I_{-} F O R$.

Table 4 presents the results of regressions. As shown in column 1, the coefficients of $I O \_D O M \_L O W$ and $I O \_F O R \_L O W$ are positive and significant at the $1 \%$ level. This suggests that shareholdings by low-stake institutions, domestic and foreign alike, are positively related to stock return comovement. Stated another way, foreign institutions with low-stake holdings rely more on common information than firm-specific information, and thus, contribute more to the incorporation of common information into stock price. In contrast, we find that the coefficients of $I O \_D O M_{-} H I G H$ and $I O \_F O R \_H I G H$ are negative and significant at the $1 \%$ level. This implies that shareholdings by high-stake institutions, domestic and foreign alike, are negatively related to stock return comovement. The above results, taken together, are consistent with our second prediction, suggesting that high-stake (low-stake) institutions facilitate the incorporation of firm-specific (common) information into stock price.

Our results corroborate the finding of previous research that high-stake institutional investors are more likely to engage in informed trading (Bushee and Goodman, 2007) and that low-stake institutional investors cannot afford the high fixed costs of acquiring firm-specific information (Ali et al., 2008), and thus are more likely to rely on common information, thereby increasing stock return comovement. To the extent that the size of institutional stakeholdings reflects the ability to bear the fixed costs of acquiring firm-specific information, our results are in line with Veldkamp's (2006) information-driven comovement theory.

To further examine whether the impact of stakeholding size on comovement differs systematically between foreign institutions that originate from different countries, we first 
Table 4 Comovement and high versus low institutional stakeholdings

\begin{tabular}{|c|c|c|c|}
\hline & (1) & (2) & (3) \\
\hline \multirow[t]{2}{*}{ IO_DOM_HIGH } & $-0.2191^{* * *}$ & $-0.2132^{* * *}$ & $-0.2121^{* * *}$ \\
\hline & $(-3.32)$ & $(-3.25)$ & $(-3.22)$ \\
\hline \multirow[t]{2}{*}{ IO_DOM_LOW } & $1.6762^{* * *}$ & $1.5321^{* * *}$ & $1.5472^{* * *}$ \\
\hline & $(9.17)$ & $(8.48)$ & $(8.57)$ \\
\hline \multirow[t]{2}{*}{ IO_FOR_HIGH $H_{t-1}$} & $-0.3521^{* * *}$ & & \\
\hline & $(-4.64)$ & & \\
\hline \multirow[t]{2}{*}{ IO_FOR_LOW } & $0.7960^{* * *}$ & & \\
\hline & $(6.26)$ & & \\
\hline \multirow[t]{2}{*}{ IO_FOR_COMMON_HIGH } & & $-0.3331^{* * *}$ & \\
\hline & & $(-4.08)$ & \\
\hline \multirow[t]{2}{*}{ IO_FOR_COMMON_LOW ${ }_{t-1}$} & & -0.2512 & \\
\hline & & $(-1.28)$ & \\
\hline \multirow[t]{2}{*}{ IO_FOR_CIVIL_HIGH $H_{t-1}$} & & -0.2241 & \\
\hline & & $(-1.20)$ & \\
\hline \multirow[t]{2}{*}{ IO_FOR_CIVIL_LOW $W_{t-1}$} & & $2.7762^{* * *}$ & \\
\hline & & $(9.10)$ & \\
\hline \multirow[t]{2}{*}{ IO_FOR_HASD_HIGH $H_{t-1}$} & & & $-0.3291^{* * *}$ \\
\hline & & & $(-4.06)$ \\
\hline \multirow[t]{2}{*}{ IO_FOR_HASD_LOW } & & & -0.1310 \\
\hline & & & $(-0.72)$ \\
\hline \multirow[t]{2}{*}{ IO_FOR_LASD_HIGH $H_{t-1}$} & & & -0.2330 \\
\hline & & & $(-1.21)$ \\
\hline \multirow[t]{2}{*}{ IO_FOR_LASD_LOW $W_{t-1}$} & & & $3.1621^{* * *}$ \\
\hline & & & $(8.83)$ \\
\hline \multirow[t]{2}{*}{$S I Z E_{t-1}$} & $0.0989^{* * *}$ & $0.1002^{* * *}$ & $0.0993^{* * *}$ \\
\hline & $(27.02)$ & $(27.39)$ & $(27.17)$ \\
\hline \multirow[t]{2}{*}{ Comovement $_{t-1}$} & $0.2221^{* * *}$ & $0.2212^{* * *}$ & $0.2201^{* * *}$ \\
\hline & $(46.54)$ & $(46.42)$ & $(46.37)$ \\
\hline \multirow[t]{2}{*}{$M B_{t-1}$} & 0.0018 & 0.0017 & 0.0017 \\
\hline & $(1.33)$ & $(1.24)$ & $(1.269)$ \\
\hline \multirow[t]{2}{*}{$L E V_{t-1}$} & $0.1181^{* * *}$ & $0.1172^{* * *}$ & $0.1161^{* * *}$ \\
\hline & $(4.10)$ & $(4.06)$ & $(4.05)$ \\
\hline \multirow[t]{2}{*}{$A C C R_{t}$} & -0.0001 & -0.0000 & -0.0000 \\
\hline & $(0.05)$ & $(-0.02)$ & $(-0.02)$ \\
\hline \multirow[t]{2}{*}{$R O A_{t}$} & $-0.2282^{* * *}$ & $-0.2251^{* * *}$ & $-0.2252^{* * *}$ \\
\hline & $(-7.02)$ & $(-6.94)$ & $(-6.94)$ \\
\hline \multirow[t]{2}{*}{ DIVERS $_{t}$} & $0.0167^{* * *}$ & $0.0166^{* * *}$ & $0.0165^{* * *}$ \\
\hline & $(8.45)$ & $(8.42)$ & $(8.41)$ \\
\hline \multirow[t]{2}{*}{ HERF } & -0.0024 & -0.0012 & -0.0019 \\
\hline & $(-0.11)$ & $(-0.06)$ & $(-0.09)$ \\
\hline \multirow[t]{2}{*}{$N I N D_{t}$} & $-0.1212^{* * *}$ & $-0.1151^{* * *}$ & $-0.1150^{* * *}$ \\
\hline & $(-5.77)$ & $(-5.49)$ & $(-5.49)$ \\
\hline \multirow[t]{2}{*}{$N A F_{t}$} & $0.0424^{* * *}$ & $0.0434^{* * *}$ & $0.0440^{* * *}$ \\
\hline & $(8.14)$ & (8.34) & $(8.45)$ \\
\hline
\end{tabular}


Table 4 Comovement and high versus low institutional stakeholdings (Continued)

\begin{tabular}{llll}
\hline & $(1)$ & $(2)$ & $(3)$ \\
\hline TURN ${ }_{t}$ & $0.3370^{* * *}$ & $0.3341^{* * *}$ & $0.3332^{* * *}$ \\
& $(12.00)$ & $(11.94)$ & $(11.91)$ \\
Intercept & $-1.2191^{* * *}$ & $-1.2782^{* * *}$ & $-1.2723^{* * *}$ \\
& $(-6.02)$ & $(-6.29)$ & $(-6.26)$ \\
No. of obs. & 54,730 & 54,730 & 54,730 \\
Adjusted $R^{2}$ & 0.342 & 0.342 & 0.343 \\
\hline
\end{tabular}

Notes. This table reports the regression analysis of stock return comovement on institutions of high- / low- stakeholdings. The sample consists of 54,730 firm-year observations drawn from 40 countries for 1997-2006. The dependent variable is Comovement . IO_DOM, IO_FOR, IO_FOR_COMMON, IO_FOR_CIVIL, IO_FOR_HASD and IO_FOR_CIVIL interact with HIGH or LOW. The coefficients and the test statistics are based on the regression model in Eq. (3). The $t$-statistics, reported in parentheses, are based on robust standard errors corrected for firm-level clustering. Year, industry and country dummies are included. Here $*^{* *},{ }^{* *}$, and ${ }^{*}$ indicate significance at the $1 \%, 5 \%$, and $10 \%$ levels, respectively. All variables are defined in Appendix A

partition foreign institutional ownership into common-law and civil-law institutional shareholdings, and then, further partition common-law into high- and low-stake holdings (IO_FOR_COMMON_HIGH and IO_FOR_COMMON_LOW, respectively). Similarly, we also decompose civil-law institutional ownership into those of high- and low-stake institutions (IO_FOR_CIVIL_HIGH and IO_FOR_CIVIL_LOW, respectively). Table 4 reports the results of regression using these finer partitions.

As shown in column 2, the coefficient of $I_{-}$FOR_COMMON_HIGH is negative and significant at the $1 \%$ level, while $I_{-} F O R_{-} C I V I L_{-} H I G H$ is insignificant. This finding suggests that high-stake foreign institutions from common-law countries contribute to a reduction in stock return comovement. The coefficient of $I O \_F O R \_C O M M O N \_L O W$ is negative but insignificant, while that of $I O \_F O R \_C I V I L \_L O W$ is positive and significant at the $1 \%$ level. This indicates that low-stake foreign institutions from civil-law countries even increase stock return comovement. Column 3 reports the similar results when we use the anti-self-dealing index to measure a country's investor protection.

We evaluate the economic impacts of various types of institutional ownership using coefficient estimates reported in column 2 of Table 4. The coefficients of IO_DOM_HIGH, IO_FOR_COMMON_HIGH and IO_FOR_CIVIL_HIGH indicate that a ten-percent increase in ownership is associated with a change of $R^{2}$ for the market model in Eq. (1) by $-0.37 \%$, $-0.57 \%$ and $-0.39 \%$, respectively. The coefficients of $I O_{-} D O M_{-} L O W, I O_{-} F O R_{-}$ COMMON_LOW and IO_FOR_CIVIL_LOW indicate that a ten-percent increase in ownership is associated with a change of $R^{2}$ by $2.56 \%,-0.44 \%$ and $4.46 \%$, respectively.

Overall, our results show that high-stake institutions are more likely to engage in the production of firm-specific information than low-stake institutions, and thus facilitate firm-specific information flow in the market. In addition, our findings also reveal that low-stake institutions are more likely to rely on common information, and thus, increase stock return comovement.

\section{Common-law versus civil-law countries}

In this section, we further examine whether legal origin and institutional infrastructure of a host country where the firm is located affect the role that foreign institutions play in facilitating firm-specific information flow. To begin with, Aggarwal et al. (2011) point out that the role of foreign institutions in promoting corporate governance 
reforms is more important in countries with weak investor protection. Thus, equity investment by foreign institutions is more likely to improve information environment and governance efficacy for firms located in countries with weak investor protection than those with strong investor protection. This leads to a prediction that the informational role of foreign institutions is greater in host countries with weak investor protection than the counterparts. Moreover, one can argue that the role of foreign institutions in facilitating firm-specific information flows can be promoted by strong legal regimes that protect investors' rights. Morck et al. (2000) find that informed investors trade more actively in countries with better protection of property rights. Foreign institution may have better incentives to engage in informed trading in common-law countries. Countries with strong investor protection attract foreign institutional investors (Leuz et al., 2009). This in turn facilitates firm-specific information flow and mitigates stock return comovement. Given the above competing predictions, it is an empirical question whether the strength of a host country's legal origin and institutional infrastructure matter in shaping the relation between foreign institutional ownership and stock return comovement.

To focus on the institutional infrastructure of host countries, we run separate regressions for subsamples based on country-level investor protection. Table 5 reports the results of various regressions similar to those in Tables 3 and 4, for firms from common-law and civil-law countries. For brevity, we report the estimated coefficients of the test variables only. First, the coefficients of $I O \_D O M$ are significantly positive for firms from civil-law countries, while they are insignificant with a positive sign for firms from common-law countries. This suggests that in countries with weak investor protection, domestic institutions tend to rely more on common information than on firm-specific information.

Second, the coefficients of $I O \_F O R$ are insignificant for firms from both civil-law and common-law countries. However, the coefficients of IO_FOR_COMMON and $I O_{-} F O R_{-} H A S D$ are significantly negative for firms from civil-law countries (as in column 2 and 3), while they are insignificant for those from common-law countries (as in column 8 and 9). The coefficients of IO_FOR_CIVIL and IO_FOR_LASD are significantly positive for firms from both civil-law and common-law countries. The findings suggest that foreign institutions in common-law countries play a more important role in facilitating the incorporation of firm-specific information into stock price than those in civil-law countries.

Third, the coefficient of $I_{-}$FOR_COMMON_HIGH is significantly negative at the $1 \%$ level for firms from civil-law countries (column 5), while insignificant for firms from common-law countries (column 11). This lends strong support to the view that foreign institutions in common-law countries are the main drivers in facilitating firm-specific information flow in the market for firms from civil-law countries, but not for firms from common-law countries.

Collectively, our analysis provides additional evidence that investor protection of host countries influence the informational role played by foreign institutional investors. Our findings are consistent with Klapper and Love (2004) and Aggarwal et al. (2011) that firm-level investor protection matters more in countries with weak investor protection. The presence of high-stake foreign institutions in common-law countries is more important for improving firm-specific information flow in civil-law countries. Firm-level 


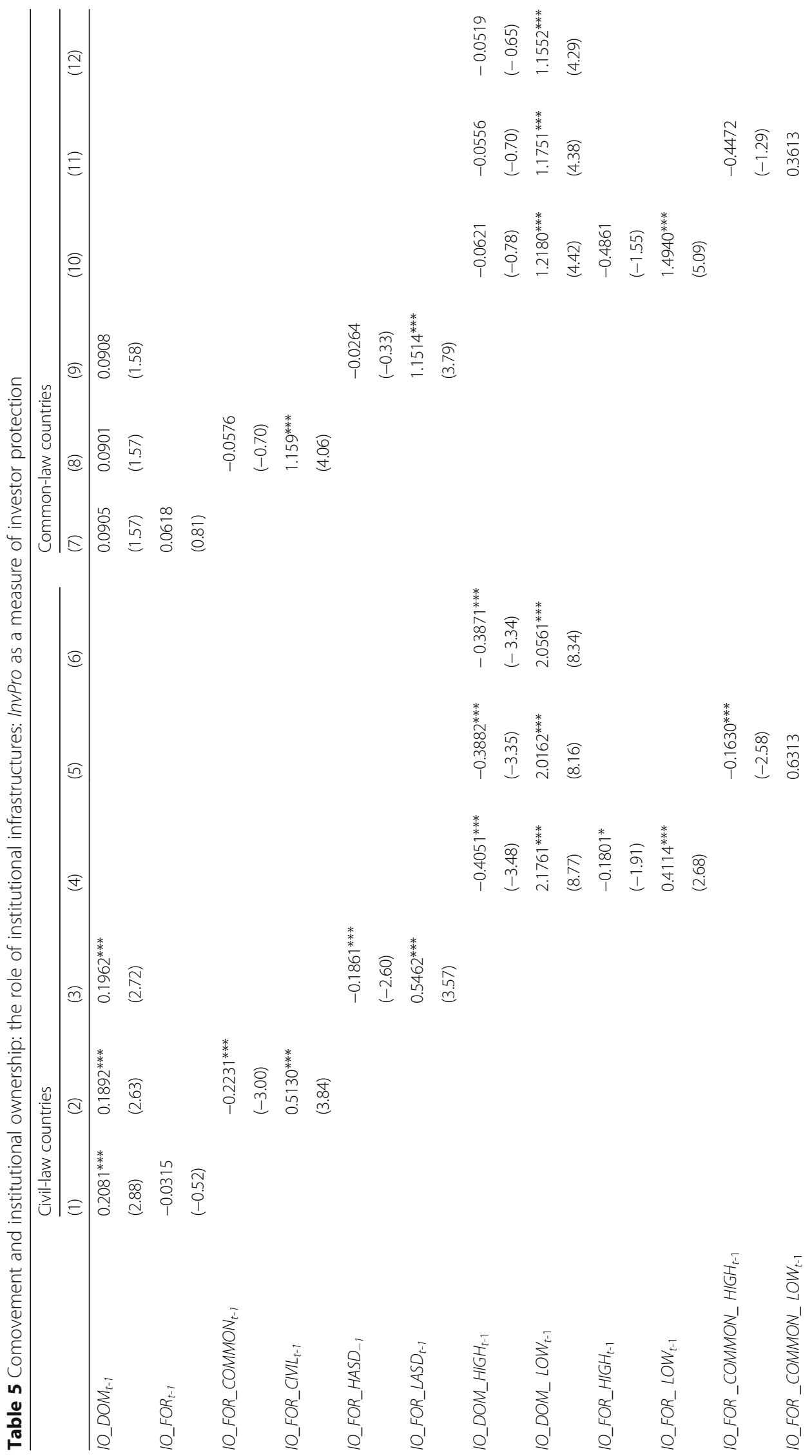




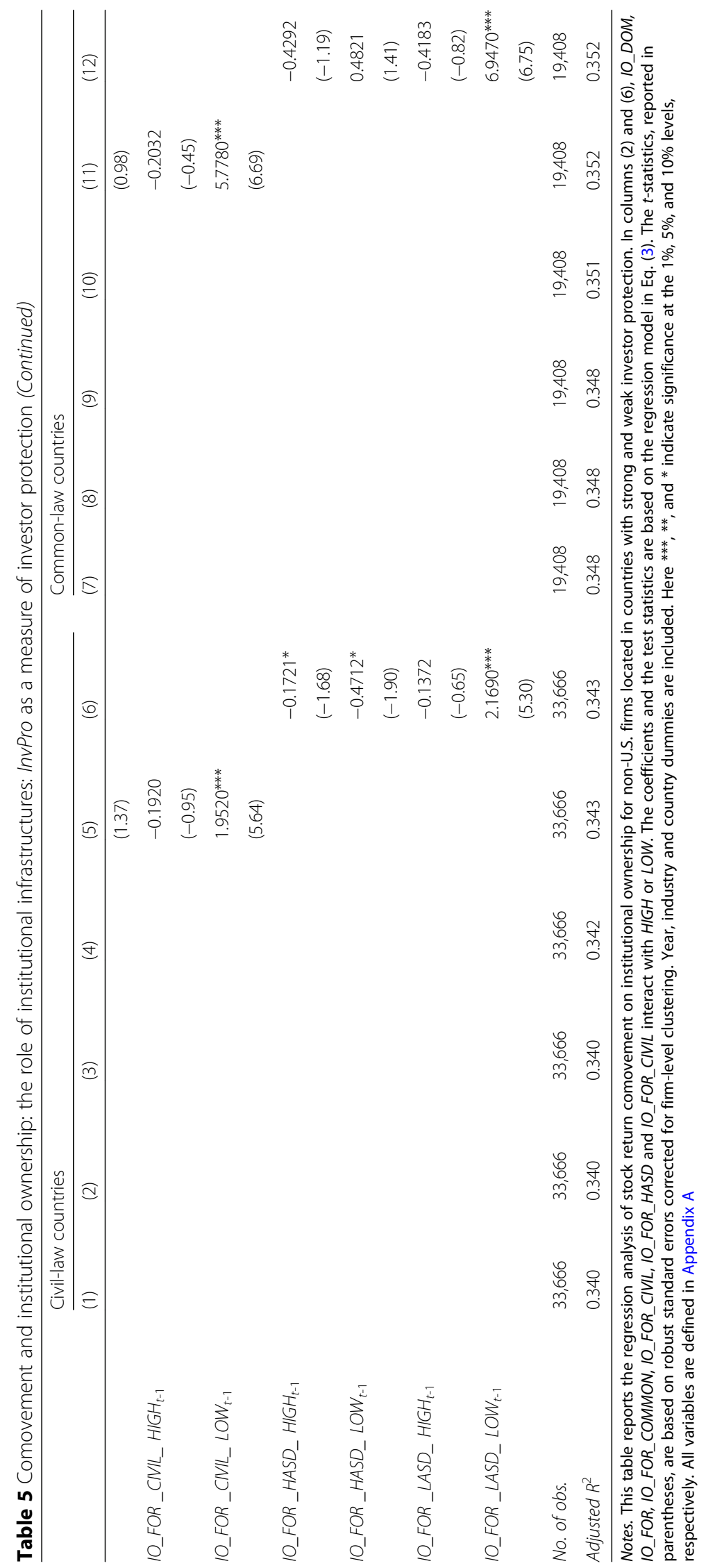


foreign institutional ownership from countries with strong investor protection mitigates the effect of weak country-level investor protection on a firm's information environment.

\section{Endogeneity issue}

Our regression specification in Eq. (3) assumes that causality runs from institutional shareholding to stock return comovement. It is possible, however, that the causality runs in the reverse direction. For example, Leuz et al. (2009) find that foreign institutional investors tend to invest less in firms with weak corporate governance, and Bushee (1998) shows that institutions prefer to invest in more transparent firms. Thus, foreign institutional investors take into account stock return comovement when constructing their investment portfolios. In such a case, an endogeneity or reverse causality problem arises. We conduct a variety of tests for the existence of endogeneity in general and reverse causality in particular.

\section{Change regressions}

To address concerns about reverse causality and omitted correlated variables, we first estimate a change regression. To the extent that omitted variables are time-invariant individual characteristics (such as fund managers' preference) that cannot be observed in the data, removing the fixed effects through differencing can address this particular endogeneity concern. ${ }^{8}$ Our objective here is to determine whether changes in institutional ownership drive subsequent changes in return comovement, but not vice versa. If the direction of causality is from institutional ownership to comovement, we can make the following directional predictions: (i) an increase in foreign institutional ownership from common-law countries leads to a decrease in stock return comovement; and (ii) an increase in domestic institutional ownership leads to an increase in stock return comovement. To validate these directional predictions, we now estimate change regressions in which changes in stock return comovement are regressed on changes in institutional ownership and changes in the same control variables used in Eq. (3). The dependent variable $\Delta$ Comovement $_{i, t}$ is changes in the return comovement from year $t-1$ to year $t$. The main explanatory variables are changes in institutional ownership $\Delta I O_{i, t-1}$ from year $t$-2 to year $t$-1. For brevity, we report the estimated coefficients of the test variables only.

We report the results of change regressions in Table 6. As shown in Panel A, the coefficient of change in domestic institutional ownership $\left(I O \_D O M\right)$ is insignificant, while the coefficients of changes in foreign institutional ownership $\left(\triangle I O_{-} F O R\right)$, changes in foreign institutional ownership from common-law countries ( $\left.\triangle I I_{-} F O R_{-} C O M M O N\right)$ and from countries with strong investor protection $\left(\triangle I O_{-} F O R_{-} H A S D\right)$ are significantly negative at the $10 \%$ level, respectively, and the coefficients of changes in foreign institutional ownership from civil-law countries $\left(\triangle I O \_F O R \_C I V I L\right)$ and from countries with weak investor protection $\left(\triangle I O \_F O R \_L A S D\right)$ are significantly positive at the $1 \%$ level, respectively. The coefficient of changes in low-stake domestic institutional ownership $\left(\triangle I O \_D O M \_L O W\right)$ is positive and significant at the $1 \%$ level, whereas the coefficients of changes in high-stake institutional ownership from common-law countries $\left(\triangle I O \_F O R \_C O M M O N_{-} H I G H\right)$ and from countries with strong investor protection are negative and significant at the 5\% level. Overall, our results in Panel A of Table 6 are in line with our main results in Tables 3 and 4, which buttress our earlier results.

We next run reverse change regressions to examine the reverse causality from changes in current comovement to changes in future institutional ownership. Specifically, we use 
Table 6 Changes in institutional ownership on changes in comovement

\begin{tabular}{|c|c|c|c|c|c|c|}
\hline \multicolumn{7}{|c|}{ Panel A: The impact of changes in institutional ownership on changes in return comovement } \\
\hline Independent variables & $(1)$ & (2) & (3) & $(4)$ & (5) & (6) \\
\hline$\Delta O_{-} D O M_{t-1}$ & $\begin{array}{l}0.0814 \\
(1.06)\end{array}$ & $\begin{array}{l}0.0715 \\
(0.93)\end{array}$ & $\begin{array}{l}0.0742 \\
(0.96)\end{array}$ & & & \\
\hline$\Delta O_{-} F O R_{t-1}$ & $\begin{array}{l}-0.2031^{*} \\
(-1.65)\end{array}$ & & & & & \\
\hline$\Delta O_{-} F O R_{-} C O M M O N_{t-1}$ & & $\begin{array}{l}-0.0372^{*} \\
(-1.95)\end{array}$ & & & & \\
\hline$\Delta O_{-} F O R_{-} C I V I L_{t-1}$ & & $\begin{array}{l}0.8032^{* * *} \\
(3.92)\end{array}$ & & & & \\
\hline$\triangle O O_{-} F O R_{-} H A S D_{t-1}$ & & & $\begin{array}{l}-0.0748^{*} \\
(-1.92)\end{array}$ & & & \\
\hline$\triangle O O_{-} F O R \_L A S D_{t-1}$ & & & $\begin{array}{l}0.7962^{* * *} \\
(3.40)\end{array}$ & & & \\
\hline$\Delta O \_D O M \_H I G H_{t-1}$ & & & & $\begin{array}{l}-0.0602 \\
(-0.57)\end{array}$ & $\begin{array}{l}-0.0644 \\
(-0.61)\end{array}$ & $\begin{array}{l}-0.0636 \\
(-0.61)\end{array}$ \\
\hline$\Delta O \_D O M \_L O W_{t-1}$ & & & & $\begin{array}{l}1.3671^{* * *} \\
(4.85)\end{array}$ & $\begin{array}{l}1.3262^{* * *} \\
(4.70)\end{array}$ & $\begin{array}{l}1.3311^{* * *} \\
(4.72)\end{array}$ \\
\hline$\Delta O_{-} F O R_{-} H I G H_{t-1}$ & & & & $\begin{array}{l}-0.0068 \\
(-1.06)\end{array}$ & & \\
\hline$\Delta O_{-} F O R_{-} L O W_{t-1}$ & & & & $\begin{array}{l}1.1691^{* * *} \\
(5.51)\end{array}$ & & \\
\hline$\Delta O \_F O R \_C O M M O N \_H I G H_{t-1}$ & & & & & $\begin{array}{l}-0.1082^{* *} \\
(-2.00)\end{array}$ & \\
\hline$\Delta O \_F O R \_C O M M O N_{-} L O W_{t-1}$ & & & & & $\begin{array}{l}0.6471^{* *} \\
(2.20)\end{array}$ & \\
\hline$\Delta O_{-} F O R \_C I V I L_{-} H I G H_{t-1}$ & & & & & $\begin{array}{l}0.4851 \\
(1.62)\end{array}$ & \\
\hline$\Delta O_{-} F O R \_C I V I L_{-} L O W_{t-1}$ & & & & & $\begin{array}{l}2.3092^{* * *} \\
(4.60)\end{array}$ & \\
\hline$\Delta O_{-} F O R_{-} H_{A S D_{-}} H I G H_{t-1}$ & & & & & & $\begin{array}{l}-0.0890^{*} \\
(-1.84)\end{array}$ \\
\hline$\triangle O_{-} F O R_{-} H A S D_{-} L O W_{t-1}$ & & & & & & $\begin{array}{l}0.6820^{* *} \\
(2.48)\end{array}$ \\
\hline$\triangle O_{-} F O R \_L A S D_{-} H I G H_{t-1}$ & & & & & & $\begin{array}{l}0.4731 \\
(1.45)\end{array}$ \\
\hline$\triangle O_{-} F O R \_L A S D_{-} L O W_{t-1}$ & & & & & & $\begin{array}{l}2.6110^{* * *} \\
(4.49)\end{array}$ \\
\hline No. of obs. & 43,942 & 43,942 & 43,942 & 43,942 & 43,942 & 43,942 \\
\hline Adjusted $R^{2}$ & 0.322 & 0.323 & 0.322 & 0.323 & 0.323 & 0.323 \\
\hline
\end{tabular}

Panel B: The impact of changes in return comovement on changes in institutional ownership

$\begin{array}{llcc}\begin{array}{l}\text { Dependent variable in the } \\ \text { reverse regression }\end{array} & \begin{array}{l}\text { Coefficient for } \Delta \\ \text { Comovement } t-1\end{array} & \text { No. of obs. } & \text { Adjusted } R^{2} \\ \text { NO_TOTAL } & \begin{array}{l}-0.0664 \\ (-1.62)\end{array} & 47,817 & 0.076 \\ \text { NO_DOM } & \begin{array}{l}-0.0365 \\ (-1.28)\end{array} & 47,817 & 0.039 \\ \text { NO_FOR } & \begin{array}{l}-0.0298 \\ (-1.06)\end{array} & 47,817 & 0.054 \\ \text { NO_FOR_COMMON } & \begin{array}{l}-0.0266 \\ (-1.12)\end{array} & 47,817 & 0.051 \\ \text { NO_FOR_CIVIL } & -0.0034 & 47,817 & 0.017 \\ & (-0.26) & & \end{array}$


Table 6 Changes in institutional ownership on changes in comovement (Continued)

\begin{tabular}{|c|c|c|c|}
\hline$\triangle O_{-} F O R \_H A S D_{t}$ & $\begin{array}{l}-0.0272 \\
(-1.08)\end{array}$ & 47,817 & 0.049 \\
\hline$\Delta O_{-} F O R_{-} L A S D_{t}$ & $\begin{array}{l}-0.0031 \\
(-0.29)\end{array}$ & 47,817 & 0.016 \\
\hline$\Delta O \_D O M \_H I G H_{t-1}$ & $\begin{array}{l}0.0034 \\
(0.16)\end{array}$ & 47,817 & 0.004 \\
\hline$\Delta O \_D O M \_L O W_{t-1}$ & $\begin{array}{l}-0.0085 \\
(-1.05)\end{array}$ & 47,817 & 0.058 \\
\hline$\Delta O_{-} F O R_{-} H I G H_{t-1}$ & $\begin{array}{l}0.0158 \\
(0.75)\end{array}$ & 47,817 & 0.005 \\
\hline$\Delta O_{-} F O R_{-} L O W_{t-1}$ & $\begin{array}{l}-0.0183^{*} \\
(-1.93)\end{array}$ & 47,817 & 0.095 \\
\hline NO_FOR_COMMON_HIGH $H_{t-1}$ & $\begin{array}{l}0.0107 \\
(0.58)\end{array}$ & 47,817 & 0.005 \\
\hline$\triangle O O_{-} F O R_{-} C O M M O N_{-} L O W_{t-1}$ & $\begin{array}{l}-0.0139^{*} \\
(-1.94)\end{array}$ & 47,817 & 0.087 \\
\hline$\Delta O_{-} F O R \_C I V I L \_H I G H_{t-1}$ & $\begin{array}{l}0.0051 \\
(0.50)\end{array}$ & 47,817 & 0.000 \\
\hline$\Delta O_{-} F O R \_C I V I L \_L O W_{t-1}$ & $\begin{array}{l}-0.0042 \\
(-0.94)\end{array}$ & 47,817 & 0.047 \\
\hline$\Delta O_{-} F O R \_H A S D_{-} H I G H_{t-1}$ & $\begin{array}{l}0.0125 \\
(0.64)\end{array}$ & 47,817 & 0.005 \\
\hline$\Delta O_{-} F O R \_H A S D_{-} L O W_{t-1}$ & $\begin{array}{l}-0.0141^{*} \\
(-1.85)\end{array}$ & 47,817 & 0.087 \\
\hline$\Delta O_{-} F O R \_L A S D_{-} H I G H_{t-1}$ & $\begin{array}{l}0.0033 \\
(0.42)\end{array}$ & 47,817 & 0.001 \\
\hline$\triangle O_{-} F O R \_L A S D_{-} L O W_{t-1}$ & $\begin{array}{l}-0.0042 \\
(-1.08)\end{array}$ & 47,817 & 0.044 \\
\hline
\end{tabular}

Notes. This table reports change regressions. Panel A reports the results of change regressions in stock return comovement from year $t-1$ to $t$ on changes in institutional ownership from year $t-2$ to $t-1$, using the sample of 43,887 firm-year observations drawn from 40 countries for 1997-2006. Panel B reports the regression of changes in institutional ownership from year $t-1$ to $t$ on changes in stock return comovement from year $t-2$ to $t-1$, using the sample of 43,942 firm-year observations drawn from 40 countries for 1997-2006. Regressions include change in the control variables (coefficients not tabulated) as specified in the following regression. The $t$-statistics, reported in parentheses, are based on robust standard errors corrected for both firm-level clustering. Year, industry and country dummies are included. Here $* * * * *$, and $*$ indicate significance at the $1 \%, 5 \%$, and $10 \%$ levels, respectively

the change in stock return comovement as the explanatory variable and the subsequent change in institutional ownership as the dependent variable, to examine whether firms with a decrease in return comovement attract more foreign institutions. We expect that, in the absence of reverse causality, changes in firm-level return comovement over time are not associated with subsequent changes in institutional ownership. We regress each of the various measures of $\Delta I O_{i, t}$ in Eq. (3) on $\Delta$ Comovement $_{i, t-1}$ and changes in the same control variables used in Eq. (3). Specifically, we estimate the following change regression:

$$
\begin{aligned}
\Delta I O_{i, t}=\alpha_{0} & +\alpha_{1} \Delta \text { Comovement }_{i, t-1}+\alpha_{2} \Delta \operatorname{SIZE}_{i, t}+\alpha_{3} \Delta M B_{i, t}+\alpha_{4} \Delta D P_{i, t} \\
& +\alpha_{5} \Delta \text { PRICE }_{i, t}+\alpha_{6} \Delta \operatorname{VOLA}_{i, t}+\alpha_{7} \Delta A G E_{i, t}+\alpha_{8} \Delta R E T_{i, t-12, t-3} \\
& +\alpha_{9} \Delta R E T_{i, t-1, t-3}+\alpha_{10} \Delta T U R N_{i, t} \\
& +(\text { Year }, \text { Industry and Country dummies })+\varepsilon_{i, t} .
\end{aligned}
$$

Panel B of Table 6 reports the results of the reverse change regressions. For brevity, we only report the estimated coefficients for the variable of interest, i.e., $\Delta$ Comovement $_{i, t-1}$, 
which are insignificant in most cases, excluding the possibility of reverse causality. In particular, the coefficient of the $\Delta$ Comovement $_{i, t-1}$ is insignificant when the dependent variables are changes in shareholdings by foreign institutions from common-law countries and countries with strong investor protection and those by high-stake institutions from common-law countries and countries with strong investor protection, suggesting that the negative relation between comovement and large holdings by foreign institutional ownership is unlikely to be driven by institutions' purchases of a stock after its comovement decreases. However, the coefficient of the $\Delta$ Comovement $_{i, t-1}$ is negative and marginally significant when the dependent variables are changes in low-stake foreign institutional ownership from civil-law countries $\left(\triangle I O_{-} F_{-} R_{-} C I V I L_{-} L O W\right)$ and low-stake foreign institutional ownership from countries with low anti-self-dealing index scores $\left(\triangle I O_{-} F O R_{-} L A S D_{-} L O W\right)$, suggesting that low-stake foreign institutional investors might be attracted by firms with a recent decrease in stock return comovement.

\section{Instrumental variable method}

To further address reverse causality, we search for instrumental variables that may trigger changes in institutional ownership, but are not endogenous to stock return comovement at the firm level. We apply two-stage least square (2SLS) tests to isolate the effect of institutional ownership on comovement. Ferreira and Matos (2008) find that domestic institutional investors prefer stocks paying dividends and foreign institutional investors are attracted by stocks with good "name value abroad." We therefore use dividend dummy $(D I V)$ as an instrumental variable for total and domestic institutional ownership. We use foreign sales $(F S A L E)$ as an instrument for foreign institutional ownership.

In the first-stage regressions, we regress total, domestic institutional ownership variables on $D I V$ and other firm characteristics in Eq. (3), and regress foreign institutional ownership variables on FSALE and other firm characteristics in Eq. (3). All explanatory variables are lagged by one period. The untabulated first-stage regression results show that domestic institutional ownership variables are positively associated with $D I V$ and foreign institutional ownership variables are positively associated with FSALE. In the second stage, we regress return comovement on the predicted institutional ownerships and control variables. As shown in Table 7, the coefficient of the predicted ownership by domestic institutions (PIO_DOM) is significantly positive. Meanwhile, the coefficients of the predicted ownership by foreign institutions from common-law countries (PIO_FOR_COMMON) and from countries with strong investor protection (PIO_FOR_HASD), high-stake institutions from common-law counties (PIO_FOR_COMMON_HIGH) and from countries with strong investor protection (PIO_FOR_HASD_HIGH), are negative and highly significant, respectively. This suggests that foreign institutions, particularly those from countries with strong investor protection, but not domestic institutions, facilitate the incorporation of firm-specific information into stock price and reduce stock return comovement, consistent with our findings in Tables 3 and 4. In contrast, the coefficients of the predicted ownership by foreign institutions from civil-law countries and from countries with weak investor protection are positive and highly significant, respectively. Our 
Table 7 Comovement and institutional ownership: two-stage least square

\begin{tabular}{|c|c|c|c|c|c|c|}
\hline Independent variables & $(1)$ & $(2)$ & (3) & (4) & $(5)$ & (6) \\
\hline \multirow[t]{2}{*}{$P I O \_D O M_{t-1}$} & $1.9741^{* * *}$ & $1.8792^{* * *}$ & $1.8821^{* * *}$ & & & \\
\hline & $(10.46)$ & $(10.01)$ & $(10.01)$ & & & \\
\hline \multirow[t]{2}{*}{ PIO_FOR ${ }_{t-1}$} & 0.3811 & & & & & \\
\hline & $(1.54)$ & & & & & \\
\hline \multirow[t]{2}{*}{ PIO_FOR_COMMON } & & $-1.2772^{* * *}$ & & & & \\
\hline & & $(-5.89)$ & & & & \\
\hline \multirow[t]{2}{*}{ PIO_FOR_CIVIL $L_{t-1}$} & & $7.1041^{* * *}$ & & & & \\
\hline & & $(10.56)$ & & & & \\
\hline \multirow[t]{2}{*}{ PIO_FOR_HASD $D_{t-1}$} & & & $-1.1131^{* * *}$ & & & \\
\hline & & & $(-5.34)$ & & & \\
\hline \multirow[t]{2}{*}{ PIO_FOR_LASD $D_{t-1}$} & & & $8.6842^{* * *}$ & & & \\
\hline & & & (9.98) & & & \\
\hline \multirow[t]{2}{*}{ PIO_DOM_HIGH $H_{t-1}$} & & & & $-29.7002^{* * *}$ & $-27.5910^{* * *}$ & $-26.9811^{* * *}$ \\
\hline & & & & $(-13.33)$ & $(-12.29)$ & $(-11.89)$ \\
\hline \multirow[t]{2}{*}{ PIO_DOM_LOW } & & & & $11.0612^{* * *}$ & $10.9910^{* * *}$ & $10.8611^{* * *}$ \\
\hline & & & & $(17.14)$ & $(16.91)$ & $(16.74)$ \\
\hline \multirow[t]{2}{*}{$P I O \_F O R_{-} H I G H_{t-1}$} & & & & $-0.4081^{* * *}$ & & \\
\hline & & & & $(-4.80)$ & & \\
\hline \multirow[t]{2}{*}{ PIO_FOR_LOW } & & & & -1.5312 & & \\
\hline & & & & $(-0.08)$ & & \\
\hline \multirow[t]{2}{*}{$P I O \_F O R \_C O M M O N \_H I G H_{t-1}$} & & & & & $-0.9721^{* * *}$ & \\
\hline & & & & & $(-6.75)$ & \\
\hline \multirow[t]{2}{*}{ PIO_FOR_COMMON_LOW } & & & & & $-4.6522^{*}$ & \\
\hline & & & & & $(-1.81)$ & \\
\hline \multirow[t]{2}{*}{ 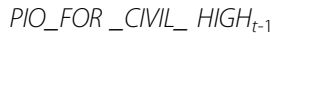 } & & & & & $4.6313^{* * *}$ & \\
\hline & & & & & $(2.82)$ & \\
\hline \multirow[t]{2}{*}{$P I O \_F O R \_C I V I L \_L O W_{t-1}$} & & & & & $5.8091^{* * *}$ & \\
\hline & & & & & $(4.64)$ & \\
\hline \multirow[t]{2}{*}{ PIO_FOR_HASD_HIGH $H_{t-1}$} & & & & & & $-0.6261^{* * *}$ \\
\hline & & & & & & $(-5.15)$ \\
\hline \multirow[t]{2}{*}{ PIO_FOR_HASD_LOW $W_{t-1}$} & & & & & & $-4.4252^{*}$ \\
\hline & & & & & & $(-1.92)$ \\
\hline \multirow[t]{2}{*}{ PIO_FOR_LASD_HIGH $H_{t-1}$} & & & & & & $3.0951^{*}$ \\
\hline & & & & & & $(1.88)$ \\
\hline \multirow[t]{2}{*}{$P I O \_F O R \_L A S D_{-} L O W_{t-1}$} & & & & & & $7.8340^{* * *}$ \\
\hline & & & & & & $(4.99)$ \\
\hline No. of obs. & 43,942 & 43,942 & 43,942 & 43,942 & 43,942 & 43,942 \\
\hline Adjusted $R^{2}$ & 0.322 & 0.323 & 0.322 & 0.323 & 0.323 & 0.323 \\
\hline
\end{tabular}

Notes. This table reports the two-stage least square regression analysis of stock return comovement on institutional ownership. The sample consists of 45,581 firm-year observations drawn from 40 countries for 1997-2006. The dependent variable is Comovement $t$. In column (2), IO_DOM, IO_FOR, IO_FOR_COMMON, IO_FOR_CIVIL, IO_FOR_HASD and IO_FOR_CIVIL interact with HIGH or LOW. The $t$-statistics, reported in parentheses, are based on robust standard errors corrected for firm-level clustering. Year, industry and country dummies are included. Here *****, and * indicate significance at the $1 \%, 5 \%$, and $10 \%$ levels, respectively. All variables are defined in Appendix A 
earlier findings hold that high-stake institutions from countries with strong investor protection reduce stock return comovment. Overall, the results from an instrumental variable approach lend further support to the view that the causality runs from institutional ownership to stock return comovement.

\section{Residual institutional ownership}

To the extent that the economic determinants of institutional ownership affect return comovement, they may introduce a spurious relation between institutional ownership and return comovement. Following Ramalingegowda and Yu (2012), we use residual institutional ownership for various types of institutions in order to address this endogeneity concern. Specifically, we estimate residual institutional ownership using a separate regression of institutional ownership on various firm-specific characteristics as specified below:

$$
\begin{aligned}
I O_{i, t}=\alpha_{0} & +\alpha_{1} S I Z E_{i, t}+\alpha_{2} M B_{i, t}+\alpha_{3} D P_{i, t}+\alpha_{4} P R I C E_{i, t}+\alpha_{5} V O L A_{i, t}+\alpha_{6} A G E_{i, t} \\
& +\alpha_{7} R E T_{i, t-12, t-3}+\alpha_{8} R E T_{i, t-1, t-3}+\alpha_{9} T_{U R N_{i, t}} \\
& +(\text { Industry, Country dummies })+\varepsilon_{i, t},
\end{aligned}
$$

where determinants of institutional ownership are chosen based on prior studies. ${ }^{9}$ We include lagged return $\left(R E T_{t-12, t-3}, R E T_{t-2, t}\right)$, stock price (PRICE), market capitalization $(S I Z E)$, age $(A G E)$, cash dividend yield $(D P)$, market to book ratio $(M B)$, annual share turnover (TURN), and return volatility (VOLA) in Eq. (5). For brevity, we do not report the results of regression in Eq. (5). ${ }^{10}$

Table 8 presents the estimates of regression of return comovement on residual institutional ownership (RIO). The coefficients of $R I O \_D O M$ and RIO_FOR are insignificant. The coefficients of RIO_FOR_COMMON and RIO_FOR_HASD are significantly negative while the coefficients of $R_{1} O_{-} F O R_{-} C I V I L$ and $R I O_{-} F O R_{-} L A S D$ are significantly positive. In addition, the coefficients of RIO_DOM_HIGH, RIO_FOR_HIGH, RIO_FOR_COMMON_HIGH and RIO_FOR_HASD_HIGH are significantly negative, while the coefficients of $R I O \_D O M \_L O W, R I O \_F O R \_L O W, R I O \_F O R \_C O M M O N \_L O W$ and $R I O \_F O R \_L A S D_{-} L O W$ are significantly positive. In short, we find that the regression results using residual institutional ownership reported in Table 8 are, in general, in line with our earlier results, which lends further support to our main results presented in Tables 3 and 4. The finding suggests that our main regression results in Tables 3 and 4 are unlikely to be driven by potential endogeneity.

\section{Robustness check}

\section{Alternative monitoring explanation}

So far, we focus on the informational role of foreign and domestic institutional investors by emphasizing their differential ability to produce firm-specific information. However, institutional investors are also known for influencing a firm's information environment through direct or indirect monitoring. Specifically, Jin and Myers (2006) point out that insiders' influence on a firm's opaqueness can affect the firm-specific information flow in the market. To examine whether monitoring is an alternative channel 
Table 8 Comovement and residual institutional ownership

\begin{tabular}{|c|c|c|c|c|c|c|}
\hline Independent variables & $(1)$ & $(2)$ & (3) & (4) & $(5)$ & (6) \\
\hline \multirow[t]{2}{*}{$R I O \_D O M_{t-1}$} & 0.0415 & 0.0329 & 0.0365 & & & \\
\hline & $(0.82)$ & $(0.66)$ & $(0.73)$ & & & \\
\hline \multirow[t]{2}{*}{$R I O_{-} F O R_{t-1}$} & -0.0149 & & & & & \\
\hline & $(-0.27)$ & & & & & \\
\hline \multirow[t]{2}{*}{$R I O \_F O R \_C O M M O N_{t-1}$} & & $-0.1813^{* * *}$ & & & & \\
\hline & & $(-2.79)$ & & & & \\
\hline \multirow[t]{2}{*}{ RIO_FOR_CIVIL $L_{t-1}$} & & $0.6061^{* * *}$ & & & & \\
\hline & & $(4.48)$ & & & & \\
\hline \multirow[t]{2}{*}{ RIO_FOR_HASD $D_{t-1}$} & & & $-0.1411^{* *}$ & & & \\
\hline & & & $(-2.27)$ & & & \\
\hline \multirow[t]{2}{*}{$R I O \_F O R \_L A S D_{t-1}$} & & & $0.6052^{* * *}$ & & & \\
\hline & & & $(3.91)$ & & & \\
\hline \multirow[t]{2}{*}{ RIO_DOM_HIGH $H_{t-1}$} & & & & $-0.2303^{* * *}$ & $-0.2221^{* * *}$ & $-0.2212^{* * *}$ \\
\hline & & & & $(-3.04)$ & $(-2.96)$ & $(-2.94)$ \\
\hline \multirow[t]{2}{*}{$R I O \_D O M \_L O W_{t-1}$} & & & & $1.0791^{* * *}$ & $0.9440^{* * *}$ & $0.9611^{* * *}$ \\
\hline & & & & $(5.67)$ & $(4.99)$ & $(5.09)$ \\
\hline \multirow[t]{2}{*}{$R I O O_{-} F O R_{-} H I G H_{t-1}$} & & & & $-0.3072^{* * *}$ & & \\
\hline & & & & $(-3.26)$ & & \\
\hline \multirow[t]{2}{*}{$R I O_{-} F O R_{-} L O W_{t-1}$} & & & & $0.6911^{* * *}$ & & \\
\hline & & & & $(4.79)$ & & \\
\hline \multirow[t]{2}{*}{$R I O_{-} F O R_{-}{ }_{C} C O M M O N_{-} H I G H_{t-1}$} & & & & & $-0.2970^{* * *}$ & \\
\hline & & & & & $(-2.85)$ & \\
\hline \multirow[t]{2}{*}{$R I O \_F O R \_C O M M O N_{-} L O W_{t-1}$} & & & & & -0.2841 & \\
\hline & & & & & $(-1.28)$ & \\
\hline \multirow[t]{2}{*}{ RIO_FOR_CIVIL_HIGH $H_{t-1}$} & & & & & -0.1861 & \\
\hline & & & & & $(-0.90)$ & \\
\hline \multirow[t]{2}{*}{$R I O_{-} F O R R_{-} C I V I L_{-} L O W_{t-1}$} & & & & & $2.422-^{* * *}$ & \\
\hline & & & & & (7.58) & \\
\hline \multirow[t]{2}{*}{ RIO_FOR_HASD_HIGH $H_{t-1}$} & & & & & & $-0.2831^{* * *}$ \\
\hline & & & & & & $(-2.77)$ \\
\hline \multirow[t]{2}{*}{ RIO_FOR_HASD_LOW ${ }_{t-1}$} & & & & & & -0.1622 \\
\hline & & & & & & $(-0.79)$ \\
\hline \multirow[t]{2}{*}{$R I O \_F O R \_L A S D_{-} H I G H_{t-1}$} & & & & & & -0.2360 \\
\hline & & & & & & $(-1.06)$ \\
\hline \multirow[t]{2}{*}{$R I O_{-} F O R \_L A S D_{-} L O W_{t-1}$} & & & & & & $2.7260^{* * *}$ \\
\hline & & & & & & $(7.29)$ \\
\hline No. of obs. & 43,942 & 43,942 & 43,942 & 43,942 & 43,942 & 43,942 \\
\hline Adjusted $R^{2}$ & 0.322 & 0.323 & 0.322 & 0.323 & 0.323 & 0.323 \\
\hline
\end{tabular}

Notes. This table reports the regression analysis of stock return comovement on residual institutional ownership. The sample consists of 43,942 firm-year observations drawn from 40 countries for 1997-2006. The dependent variable is Comovement $t$. In column (2), IO_DOM, IO_FOR, IO_FOR_COMMON, IO_FOR_CIVIL, IO_FOR_HASD and IO_FOR_CIVIL are interacted with HIGH or LOW. The $t$-statistics, reported in parentheses, are based on robust standard errors corrected for firm-level clustering. Year, industry and country dummies are included. Here ${ }^{* * *}, *^{*}$, and ${ }^{*}$ indicate significance at the $1 \%$, $5 \%$, and $10 \%$ levels, respectively. All variables are defined in Appendix A 
through which institutional investors influence corporate disclosure and reduce stock return comovement, we run the baseline regression of stock return comovement on various institutions that are likely to monitor management. Ferreira and Matos (2008) show that foreign and independent institutional investors are active in monitoring. Chen et al. (2007) show that long-term independent institutional investors tend to play the monitoring role in improving a firm's corporate governance.

Table 9 reports the estimates of the regression on independent institutions such as pension and mutual funds as well as long-term institutions. We classify institutions based on their country of origin and investment horizons. Yan and Zhang (2009) classify institutional investors into short- and long-term investors on the basis of their portfolio turnover (churn rate) over the past four quarters. For each quarter, they sort all institutional investors into three tertile portfolios based on average churn rate over the past four quarters. Those ranked in the top (bottom) tertile with highest (lowest) average churn rate are classified as short-term (long-term) institutional investors. We identify long-term and short-term institutional investors following their procedure.

Among the institutions with monitoring potential, foreign pension funds or mutual funds do not reduce stock return comovement, neither do long-term institutional investors. In contrast, short-term foreign institutional investors from common-law countries significantly reduce stock return comovement. Overall, although we cannot completely exclude the monitoring explanation, our evidence appears to support the trading-based explanation.

\section{Controlling for country-level effect}

Thus far, reported $t$-values for regression coefficients are on an adjusted basis using standard errors corrected for firm-level clustering. Given that our sample firms are from 40 countries with differing levels of economic development and institutional infrastructure, we repeat our regression analysis, and make inferences on estimated coefficients, using standard errors corrected for country-level clustering. Untabulated results show that the use of country-level clustering does not alter our results, suggesting that our regression results are robust to the use of different clustering approaches.

\section{Conclusion}

This study examines whether foreign institutional investors affect firms' information environment and mitigate excess stock return comovement. We find that foreign institutions, particularly those from countries with strong investor protection, play a more significant role than domestic institutions in incorporating firm-specific information into stock price, because such foreign institutions tend to have greater access to global private information and relatively superior information processing skills. We also find that high-stake foreign institutions contribute more to the reduction of excess stock return comovement, suggesting that the size of equity stake allows them to cope effectively with high fixed costs for producing firm-specific information. Using subsamples based on country-level investor protection, we further show that foreign institutions 
Table 9 Additional test: potential monitoring institutional investors

\begin{tabular}{|c|c|c|c|c|c|c|}
\hline & $(1)$ & $(2)$ & (3) & $(4)$ & (5) & (6) \\
\hline \multirow[t]{2}{*}{ 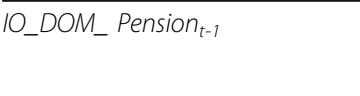 } & -0.4091 & -0.4102 & & & & \\
\hline & $(-1.06)$ & $(-1.06)$ & & & & \\
\hline \multirow[t]{2}{*}{ IO_FOR_Pensiont ${ }_{t-1}$} & 0.8352 & & & & & \\
\hline & $(0.59)$ & & & & & \\
\hline \multirow[t]{2}{*}{ IO_FOR_COMMON_Pension ${ }_{t-1}$} & & 0.9004 & & & & \\
\hline & & $(0.59)$ & & & & \\
\hline \multirow[t]{2}{*}{ IO_FOR_CIVIL_Pension ${ }_{t-1}$} & & 0.4143 & & & & \\
\hline & & $(0.10)$ & & & & \\
\hline \multirow[t]{2}{*}{ IO_DOM_Mutual $t_{t-1}$} & & & $0.1810^{*}$ & $0.1821^{*}$ & & \\
\hline & & & $(1.90)$ & $(1.92)$ & & \\
\hline \multirow[t]{2}{*}{ IO_FOR_Mutual $\left.\right|_{t-1}$} & & & -0.0002 & & & \\
\hline & & & $(-0.00)$ & & & \\
\hline \multirow[t]{2}{*}{ IO_FOR_COMMON_Mutual $\left.\right|_{t-1}$} & & & & -0.1602 & & \\
\hline & & & & $(-1.34)$ & & \\
\hline \multirow[t]{2}{*}{ IO_FOR_CIVIL_Mutual $\left.\right|_{t-1}$} & & & & 0.1941 & & \\
\hline & & & & $(1.51)$ & & \\
\hline \multirow[t]{2}{*}{ IO_DOM_LongTerm ${ }_{t-1}$} & & & & & -0.0028 & -0.0028 \\
\hline & & & & & $(-0.94)$ & $(-0.96)$ \\
\hline \multirow[t]{2}{*}{ IO_DOM_ShortTerm ${ }_{t-1}$} & & & & & -0.0026 & -0.0026 \\
\hline & & & & & $(-1.24)$ & $(-1.25)$ \\
\hline \multirow[t]{2}{*}{ IO_FOR_LongTerm ${ }_{t-1}$} & & & & & -0.0731 & \\
\hline & & & & & $(-0.72)$ & \\
\hline \multirow[t]{2}{*}{ 10_FOR_ShortTerm ${ }_{t-1}$} & & & & & 0.1083 & \\
\hline & & & & & $(0.81)$ & \\
\hline \multirow[t]{2}{*}{ IO_FOR_COMMON_LongTerm ${ }_{t-1}$} & & & & & & -0.1452 \\
\hline & & & & & & $(-1.20)$ \\
\hline \multirow[t]{2}{*}{ IO_FOR_COMMON_ShortTerm ${ }_{t-1}$} & & & & & & $-1.0673^{* * *}$ \\
\hline & & & & & & $(-2.84)$ \\
\hline \multirow[t]{2}{*}{ IO_FOR_CIVIL_LongTerm t-1 } & & & & & & 0.0997 \\
\hline & & & & & & $(0.48)$ \\
\hline \multirow[t]{2}{*}{ IO_FOR_CIVIL_ShortTerm ${ }_{t-1}$} & & & & & & $0.3271^{* *}$ \\
\hline & & & & & & $(2.39)$ \\
\hline No. of obs. & 54,730 & 54,730 & 54,730 & 54,730 & 54,730 & 54,730 \\
\hline Adjusted $R^{2}$ & 0.342 & 0.342 & 0.342 & 0.342 & 0.342 & 0.342 \\
\hline
\end{tabular}

Notes. This table reports the regression analysis of stock return comovement on potential monitoring institutions. The sample consists of 54,730 firm-year observations drawn from 40 countries for 1997-2006. The dependent variable is Comovement $t$. The coefficients and the test statistics are based on the regression model in Eq. (3). The $t$-statistics, reported in parentheses, are based on robust standard errors corrected for firm-level clustering. Year, industry and country dummies are included. Here ${ }^{* * *}, * *$, and ${ }^{*}$ indicate significance at the $1 \%, 5 \%$, and $10 \%$ levels, respectively. All variables are defined in Appendix A

from countries with strong investor protection are the main drivers in reducing excess stock return comovement in countries with weak investor protection.

Our results provide important policy implications. Given that foreign institutions from countries with strong investor protection matter more in facilitating firm-specific information flow in countries with weak investor protection, firms from emerging 
markets should attract foreign institutional investors, particularly those from countries with strong investor protection, to take large equity stakes in their firms. The finding that firm-level foreign institutional ownership mitigates the effect of weak investor protection at the country level suggests that reducing excess stock return comovement can be achieved with the help of foreign institutional investors.

\section{Endnotes}

${ }^{1}$ Alternatively, Jin and Myers (2006) link insiders' incentives for private control benefits to a firm's opaqueness and stock return comovement. They argue that insiders absorb a portion of firm-specific risk so as to capture the firm's cash flow beyond the level expected by outsiders. Barberis et al. (2005) provide evidence supporting a friction- or sentimentbased comovement theory, which focuses on frictions due to limits to arbitrage and correlated sentiments among irrational investors.

${ }^{2}$ Investors choose common information because complementarities in information demand make common information affordable. For example, they cluster their information production on bellwether stocks to gauge industry-wide information and use this information to evaluate other related stocks in the same industry (Veldkamp, 2006).

${ }^{3}$ Admati and Pfleiderer (1988) examine whether an information owner sells information directly to investors or trades on the information by creating a mutual fund. The latter can control the effects of competition among these indirectly informed traders.

${ }^{4}$ Jin and Myers (2006) argue that insiders' incentives to capture unexpected cash flow affect the firm's disclosure quality and stock return comovement. This suggests a potential link between corporate governance and stock price informativeness.

${ }^{5}$ Similar to Ferreira and Matos (2008), we consider the institutional investors domiciled in 27 countries.

${ }^{6}$ We restrict our analysis to fiscal year-end institutional holdings, rather than quarterly, for consistency across counties.

${ }^{7}$ The inclusion of U.S. stock market returns in the model is important for the following reasons: U.S. market index returns reflect global factors, liquidity changes, or informational shocks that may affect U.S. investors' trading abroad (Wongswan, 2006). The inclusion of U.S. market returns accounts for the possibility that U.S. investors transmit liquidity or informational shocks from the U.S. market to foreign markets, thus causing excess return comovement among foreign stocks.

${ }^{8}$ Our regression analysis in Tables 3 and 4 has used the level of institutional ownership as the test variable, and the results shed light on the holding effect of institutional investors. Boehmer and Kelley (2009) show that "the level of institutional holdings has a direct effect on efficiency that is orthogonal to the effect of trading" (p. 3565).

${ }^{9}$ Gompers and Metrick (2001) find that U.S. institutions invest in larger and more liquid stocks with relatively low past returns. Kang and Stulz (1997) find that foreign investors tend to invest in larger and more established firms in Japan. Ferreira and Matos (2008) find that U.S. institutions prefer to invest in value (low $M B$ ) stocks. Covrig et al. (2006) show that both domestic and foreign institutional investors prefer stocks with high turnover and low volatility.

${ }^{10}$ The full results are available from the authors upon request. 


\section{Appendix A}

Variable definitions

Dependent Variable: Comovement

Comovement is a measure of market-wide information arriving to the securities market based on $R^{2}$ from the expanded market model regression,

$$
\begin{aligned}
r_{i, t}=\alpha_{j} & +\beta_{1, t} r_{m, j, t-1}+\beta_{2, t}\left(r_{u s, t-1}+e_{j, t-1}\right)+\beta_{3, t} r_{m, j, t}+\beta_{4, t}\left(r_{u s, t}+e_{j, t}\right)+\beta_{5, t} r_{m, j, t+1} \\
& +\beta_{6, t}\left(r_{u s, t+1}+e_{j, t+1}\right)+\varepsilon_{j, t} .
\end{aligned}
$$

Specifically, Comovement $=\ln \left(R^{2} /\left(1-R^{2}\right)\right)$.

\section{Institutional Ownership Variables}

IO_TOTAL is total institutional ownership, as the sum of shareholdings of all institutions for a stock divided by its total number of shares outstanding.

$I O \_D O M$ is domestic institutional ownership, as the sum of shareholdings of all institutions headquartered in the same country where a stock is listed divided by its total number of shares outstanding.

$I O \_F O R$ is foreign institutional ownership, as the sum of shareholdings of all institutions headquartered in foreign countries, i.e., countries different from the country in which a stock is listed, divided by its total number of shares outstanding.

IO_FOR_COMMON is the sum of the shareholdings of all institutions headquartered in common-law countries divided by the total number of shares outstanding.

IO_FOR_CIVIL is the sum of the shareholdings of all institutions headquartered in civil-law countries divided by the total number of shares outstanding.

IO_FOR_HASD is the sum of the shareholdings of all institutions headquartered in countries with above-median anti-self-dealing index scores divided by the total number of shares outstanding.

IO_FOR_LASD is the sum of the shareholdings of all institutions headquartered in countries with below-median anti-self-dealing index scores divided by the total number of shares outstanding.

IO_DOM_HIGH is domestic high-stake institutional ownership, as the sum of the shareholdings by institutions headquartered in the same countries, with more than $5 \%$ shareholdings in a stock divided by its total number of shares outstanding.

IO_DOM_LOW is domestic low-stake institutional ownership, as the sum of the shareholdings by institutions headquartered in the same country, with less than $1 \%$ shareholdings in a stock divided by its total number of shares outstanding.

IO_FOR_HIGH is foreign high-stake institutional ownership, as the sum of the shareholdings by institutions headquartered in foreign countries, with more than $5 \%$ shareholdings in a stock divided by its total number of shares outstanding.

IO_FOR_LOW is foreign low-stake institutional ownership, as the sum of the shareholdings by institutions headquartered in foreign countries, with less than $1 \%$ shareholdings in a stock divided by its total number of shares outstanding.

IO_FOR_COMMON_HIGH is common-law, high-stake institutional ownership, as the sum of the shareholdings by institutions headquartered in common law countries, with more than $5 \%$ shareholdings in a stock divided by its total number of shares outstanding. 
IO_FOR_COMMON_LOW is common-law, low-stake institutional ownership, as the sum of the shareholdings by institutions headquartered in common law countries, with less than $1 \%$ shareholdings in a stock divided by its total number of shares outstanding. IO_FOR_CIVIL_HIGH is civil-law, high-stake institutional ownership, as the sum of the shareholdings by institutions headquartered in civil law countries, with more than $5 \%$ shareholdings in a stock divided by its total number of shares outstanding.

IO_FOR_CIVIL_LOW is civil-law low-stake institutional ownership, as the sum of the shareholdings by institutions headquartered in civil law countries, with less than $1 \%$ shareholdings in a stock divided by its total number of shares outstanding.

IO_FOR_HASD_HIGH is high anti-self-dealing index, high-stake institutional ownership, as the sum of the shareholdings by institutions headquartered in countries with above median anti-self-dealing index scores, with more than 5\% shareholdings in a stock divided by its total number of shares outstanding.

$I O \_F O R \_H A S D \_L O W$ is high anti-self-dealing index, low-stake institutional ownership, as the sum of the shareholdings by institutions headquartered in countries with above median anti-self-dealing index scores, with less than $1 \%$ shareholdings in a stock divided by its total number of shares outstanding.

IO_FOR_LASD_HIGH is low anti-self-dealing index, high-stake institutional ownership, as the sum of the shareholdings by institutions headquartered in countries with below median anti-self-dealing index scores, with more than $5 \%$ shareholdings in a stock divided by its total number of shares outstanding.

$I O \_F O R \_L A S D \_L O W$ is low anti-self-dealing index, low-stake institutional ownership, as the sum of the shareholdings by institutions headquartered in countries with below median anti-self-dealing index scores, with less than $1 \%$ shareholdings in a stock divided by its total number of shares outstanding.

\section{Firm-specific Control Variables}

SIZE is the natural log of market capitalization at the end of the fiscal year (in millions of U.S. dollars).

$M B$ is the ratio of market value of equity to the book value of equity at the end of the fiscal year.

$L E V$ is the book value of long-term debt scaled by the sum of market value of equity and book value of long-term debt at the end of the fiscal year.

$A C C R$ is the absolute value of total accounting accruals scaled by total operating cash flows.

$R O A$ is the income before extraordinary items divided by the beginning-of-fiscal year total assets.

DIVERS is the number of business segments.

$H E R F$ is the revenue-based Herfindahl index of industry-level concentration, calculated with the revenues of all firms within each country.

NIND is the natural log of the number of firms in each industry used to calculate HERF.

$N A F$ is the natural log of number of analysts issuing forecasts for the firm during the fiscal year.

TURN is annual share turnover over the current year, where share turnover is calculated as the average monthly trading volume divided by the total number of shares outstanding during the month. 
IndustryDummies are industry indicators based on two-digit SIC codes.

$D P$ is dividend yield, calculated as cash dividend divided by share price.

PRICE is the natural log of per share stock price (in U.S. dollars).

$V O L A$ is the volatility estimated as the standard deviation of monthly returns over the previous two fiscal years.

$A G E$ is firm age, calculated as the log of the number of months since the first return appears in Datastream.

$R E L_{t-2, t-1}$ is cumulative gross returns over the past 3 months.

$R E L_{t-12, t-3}$ is cumulative gross returns over the 9 months preceding the beginning of the filing quarter.

FSALE is the foreign sales divided by total sales at the end of the fiscal year.

\section{Country-Level Governance}

Legal regime: The legal origin of the company law or commercial code of each country. Equals one if the origin is common law, and zero otherwise. Source: La Porta et al. (1998).

Anti-self-dealing index: Average of ex ante and ex post private control of self-dealing. Index of ex ante control of self-dealing transactions is based on the average of approval by disinterested shareholders and ex ante disclosure. Index of ex post control over self-dealing transactions is based on the average of disclosure in periodic filings and ease of proving wrongdoing. First principal component of: (1) approval by disinterested shareholders; (2) disclosures by Buyer; (3) disclosures by the insider self-dealer; (4) independent review; (5) each of the elements in the index of disclosure in periodic filings; (6) standing to sue; (7) rescission; (8) ease of holding the insider self-dealer liable; (9) ease of holding the approving body liable; and (10) access to evidence. The index ranges from zero (weak private enforcement) to one (strong private enforcement). Source: Djankov et al. (2008).

Availability of data and materials

The data used are publicly available from the sources cited in the text.

Authors' contributions

$\mathrm{L}$ contributed to the overall writing; JK conceived the idea; and LP contributed to the data processing and writing of the initial draft. All authors read and approved the final manuscript.

Competing interests

The authors declare that they have no competing interests.

\section{Publisher's Note}

Springer Nature remains neutral with regard to jurisdictional claims in published maps and institutional affiliations.

Author details

${ }^{1}$ School of Accounting and Finance, Hong Kong Polytechnic University, Hong Kong, China. ${ }^{2}$ Department of Accountancy, City University of Hong Kong, Hong Kong, China. ${ }^{3}$ Hang Seng Investment Management, Hong Kong, China.

Received: 23 March 2018 Accepted: 10 July 2018

Published online: 04 September 2018

References

Admati, A. R., \& Pfleiderer, P. (1988). Selling and trading on information in financial markets. American Economic Review, 78, 96-103.

Aggarwal, R., Erel, l., Ferreira, M., \& Matos, P. (2011). Does governance travel around the world? Evidence from institutional investors. Journal of Financial Economics, 100, 154-181.

Albuquerque, R., Bauer, G. H., \& Schneider, M. (2009). Global private information in international equity markets. Journal of Financial Economics, 94, 18-46. 
Ali, A., Klasa, S., \& Li, O. Z. (2008). Institutional stakeholdings and better-informed traders at earnings announcements. Journal of Accounting and Economics, 46, 47-61.

Bailey, W., Mao, C. X., \& Sirodom, K. (2007). Investment restrictions and the cross-border flow of information: Some empirical evidence. Journal of International Money and Finance, 26, 1-25.

Barberis, N., Shleifer, A., \& Wurgler, F. (2005). Comovement. Journal of Financial Economics, 75, 283-317.

Boehmer, E., \& Kelley, E. K. (2009). Institutional investors and the informational efficiency of prices. Review of Financial Studies, 22, 3563-3594.

Brockman, P., \& Yan, X. (2009). Block ownership and firm-specific information. Journal of Banking and Finance, 33, 308-316.

Brockman, P., Liebenberg, I., \& Schutte, M. (2010). Comovement, information production, and the business cycle. Journal of Financial Economics, 97, 107-129.

Bushee, B. J. (1998). The influence of institutional investors on myopic R\&D investment behavior. The Accounting Review, 73, 305-333.

Bushee, B. J., \& Goodman, T. H. (2007). Which institutional investors trade based on private information about earning and returns? Journal of Accounting Research, 45, 289-322.

Chen, X., Harford, J., \& Li, K. (2007). Monitoring: Which institutions matter? Journal of Financial Economics, 86, 279-305.

Covrig, V., Lau, S. T., \& Ng, L. (2006). Do domestic and foreign fund managers have similar preferences for stock characteristics? A cross-country analysis. Journal of International Business Studies, 47, 407-429.

Dimson, E. (1979). Risk measurement when shares are subject to infrequent trading. Journal of Financial Economics, 7, $197-226$.

Djankov, S., La Porta, R., Lopez-de-Silanes, F., \& Shleifer, A. (2008). The law and economics of self-dealing. Journal of Financial Economics, 88, 430-465.

Durnev, A., Morck, R., Yeung, B., \& Zarowin, P. (2003). Does greater form-specific return variation mean more or less informed stock pricing? Journal of Accounting Research, 41, 797-836.

Fernandes, N., \& Ferreira, M. A. (2008). Does international cross-listing improve investment efficiency? Journal of Financial Economics, 88, 216-244.

Fernandes, N., \& Ferreira, M. A. (2009). Insider trading law and stock price informativeness. Review of Financial Studies, $22,1845-1887$.

Ferreira, M. A., \& Laux, P. A. (2007). Corporate governance, idiosyncratic risk and information flow. Journal of Finance, 62, 951-989.

Ferreira, M. A., \& Matos, P. (2008). The colors of investors' money: The role of institutional investors around the world. Journal of Financial Economics, 88, 99-533.

French, K., \& Roll, R. (1986). Stock return variances: The arrival of information and the reaction of traders. Journal of Financial Economics, 17, 5-26.

Gillan, S., \& Starks, L. T. (2003). Corporate governance, corporate ownership, and the role of institutional investors: A global perspective. Journal of Applied Finance, 13, 4-22.

Gompers, P. A., \& Metrick, A. (2001). Institutional investors and equity prices. Quarterly Journal of Economics, 116, 229-259.

Gul, F. A., Kim, J.-B., \& Qiu, A. (2009). Ownership concentration, foreign shareholding, audit quality, and stock price synchronicity: Evidence from China. Journal of Financial Economics, 95, 425-442.

Hameed, A., Morck, R., Shen, J., \& Yeung, B. (2015). Information, analysts, and stock return comovement. Review of Financial Studies, 28, 3153-3187.

Hutton, A.r Marcus, A., \& Tehranian, H. (2009). Opaque financial reports, R2, and crash risk. Journal of Financial Economics, 94, 67-86.

Jin, L., \& Myers, S. (2006). R² around the world: New theory and new tests. Journal of Financial Economics, 79, 257-292.

Kang, J. K., \& Stulz, R. (1997). Why is there a home bias? An analysis of foreign portfolio equity ownership in Japan. Journal of Financial Economics, 46, 3-28.

Karolyi, A. (2006). The world of cross-listings and cross-listings of the world: Challenging conventional wisdom. Review of Finance, 10(1), 99-152.

Kim, J.-B., \& Shi, H. (2012). IFRS reporting, firm-specific information flows, and institutional environments: International evidence. Review of Accounting Studies, 17, 474-517.

Klapper, L. F., \& Love, I. (2004). Corporate governance, investor protection, and performance in emerging markets. Journal of Corporate Finance, 10, 703-728.

La Porta, R., Lopez-de-Silanes, F., Shleifer, A., \& Vishny, R. (1998). Law and finance. Journal of Political Economy, 106, 1113-1155.

Leuz, C., Lins, K. V., \& Warnock, F. E. (2009). Do foreigners invest less in poorly governed firms? Review of Financial Studies, 22, 3246-3285.

Morck, R., Yeung, B., \& Yu, W. (2000). The information content of stock markets: Why do emerging markets have synchronous stock price movements? Journal of Financial Economics, 59, 215-260.

Petersen, M. A. (2009). Estimating standard errors in finance panel data sets: Comparing approaches. Review of Financial Studies, 22, 435-480

Piotroski, J. D., \& Roulstone, D. T. (2004). The influence of analysts, institutional investors, and insiders on the incorporation of market, industry, and firm-specific information into stock price. The Accounting Review, 79, 1119-1151.

Ramalingegowda, S., \& Yu, Y. (2012). Institutional ownership and conservatism. Journal of Accounting and Economics, 53, $98-114$.

Roll, R. (1988). R². Journal of Finance, 43, 541-566.

Veldkamp, L. (2006). Information markets and the comovement of asset prices. Review of Economic Studies, 73, 823-845.

Wongswan, J. (2006). Transmission of information across international equity markets. Review of Financial Studies, 19, $1158-1189$.

Yan, X. S., \& Zhang, Z. (2009). Institutional investors and equity returns: Are short-term investors better informed? Review of Financial Studies, 22, 893-924.

Ye, P. (2012). The value of active investing: Can active institutional investors remove excess comovement of stock returns? Journal of Financial and Quantitative Analysis, 47, 667-688. 